\title{
Epigenetics: an alternative pathway in GISTs tumorigenesis
}

\author{
Minireview
}

\author{
K. JASEK ${ }^{1, *}$, I. KASUBOVA ${ }^{1}$, V. HOLUBEKOVA ${ }^{1}$, A. STANCLOVA ${ }^{2}$, L. PLANK ${ }^{1,2}$, Z. LASABOVA ${ }^{1,3}$
}

${ }^{1}$ Biomedical Center Martin, Jessenius Faculty of Medicine in Martin, Comenius University in Bratislava, Martin, Slovakia; ${ }^{2}$ Department of Pathological Anatomy, Jessenius Faculty of Medicine in Martin, Comenius University in Bratislava, Martin, Slovakia; ${ }^{3}$ Department of Molecular Biology, Jessenius Faculty of Medicine in Martin, Comenius University in Bratislava, Martin, Slovakia

*Correspondence: karin.jasek@jfmed.uniba.sk

Received July 26, 2017 / Accepted March 15, 2018

\begin{abstract}
Many diseases have different pathological backgrounds responsible for abnormal cell behavior and exhibiting altered function and signal transduction. This is especially true for tumors and although changes affecting DNA sequence, irreversible mutations and chromosomal aberrations in gastrointestinal stromal tumors (GISTs) have been widely studied, the importance of reversible epigenetic changes increasingly recognized in many cancers has received insufficient attention in these tumors. Epigenetic mechanisms are part of normal development and gene expression under normal conditions, but malfunction of these processes leads to malignant transformation by disturbing both intra- and intercellular communication. GISTs are a specific group of gastrointestinal tract tumors resistant to conventional chemotherapy and radiotherapy. Although they account for only $1 \%$ to $2 \%$ of tumors, they are among the most widespread gastrointestinal mesenchymal tumors. DNA hyper/hypomethylation overexpression/underexpression of miRNAs or abnormal histone modification may provide an alternative to the genetic modifications responsible for GIST pathology, response to treatment, prognosis and overall survival. This review summarizes the known epigenetic mechanisms involved in GIST pathogenesis; including onset, progression, and GISTs resistance. Reversible epigenetic changes are a novel and appropriate approach to halt the spread of metastases and the emergence of resistance in GIST treatment, and these changes depend on the type of epigenetic alternation, including inhibitors of histone acetyltranferase and deacetylase and DNA methyltransferases.
\end{abstract}

Key words: epigenetics, GISTs, methylation, histone modification, miRNAs

\section{Characteristic mutations in gastrointestinal stromal tumor (GISTs)}

GISTs are defined as mesenchymal tumors with characteristic morphology which stem from the gastrointestinal tract (GIT) walls or nearby organs. [1]. Despite their 1-2\% rarity in primary GIT tumors, they are the most common mesenchymal tumors [2]. They predominantly occur in the stomach and small intestine [3] and are believed to originate from interstitial Cajal cells (ICC's) or their precursors [3, 4]. Over $80 \%$ of GISTs carry a gain-of-function mutation in the $K I T$ gene which leads to constitutive activation of the KIT receptor.
In contrast, approximately one third of GISTs without KIT mutation have a deregulated PDGFRa receptor encoded by that gene [5]. Although almost all mutations occur in KIT exons 9, 11, 13, or 17 and PDGFRa exons 12, 14 and 18 $[6,7]$, studies now reveal mutations in KIT exons $2,8,10$, 14,15 and $18[3,5,8]$. A further factor in GISTs tumorigenesis has recently been identified [9]. This involves the ETV1 gene which is closely related to KIT signaling [10] and is also expressed in ICC cells. A mutated KIT receptor helps maintain ETV1 protein stability, and together they contribute to GIST oncogenesis $[10,11]$. In addition, mechanisms affecting RNA stability are considered responsible for ETV1 deregulation. 
GISTs and their progression are also associated with the following genetic and epigenetic abnormalities [12]: cytogenetic analyses revealed frequent losses at 14q, 22q [13], 1q, $13 q$ and $15 q$ [5]. Moreover, loss of the 4q13.2 locus in the UGT2B17 gene has been observed in GISTs $[14,15]$ and while deletion in this gene correlates with prostate cancer risk [15], its importance in GISTs requires further analysis. Interestingly, chromosomal aberration does not accompany wild type GISTs (WT GISTs) [5].

The remaining heterogenous GISTs are referred to as wild type GISTs (WT-GISTs or KIT/PDGFRa WT GISTs). They have no detectable KIT/PDGFRa mutations, but harbor mutations of other genes such as $S D H$ (succinate dehydrogenase), $B-R A F$ and $K-R A S$ [1]. Other related loss-of-function mutations in KIT/PDGFRa WT GISTs are linked to neurofibromatosis from NF1 gene aberrations [3,5] and a newly recognised GIST group now makes up a proportion of KIT/ PDGFRa WT GISTs [5]. While these are characterized by loss of function in the SDH complex [16], deregulation may be caused genetically by mutations or epigenetically by miRNA and hypermethylation [16-19]. Succinate dehydrogenase $(\mathrm{SDH})$ is located in the inner mitochondrial membrane and this is the enzyme complex participating in the Krebs cycle and involved in the respiratory chain. It has four subunits: SDHA, SDHB, SDHC, SDHD $[18,20]$ encoded by four different genes.

Failure of the SDH complex can induce cell hypoxic conditions that disrupt metabolic regulation $[17,21]$ and lead to accumulation of specific metabolites which cause epigenetic changes in the genome [17]. KIT/PDGFRa negative GISTs are divided into two main groups according to immunohistochemical staining (IHC) of succinate dehydrogenase subunit $\mathrm{B}(S D H B)[18,22]$. The $S D H B$ positive group $\left(S D H B^{I H C+}\right)$ is accompanied by expression of the SDHB protein and the negative group $\left(S D H B^{I H C-}\right)$ is characterized by little or no expression of SDHB protein [18].

Although GIST tyrosine kinase mutations were considered mutually exclusive and $S D H x$ mutations were characteristic for KIT/PDGFR $\alpha$ negative GISTs, a significant finding in whole exome sequencing identified the first concomitant somatic mutations in PDGFR $\alpha$ gene (D842V) and frameshift mutation in the $S D H B$ gene. Since $S D H$-deficient patients responded poorly to treatment with tyrosine kinase inhibitors $[22,23]$, this discovery may bring new diagnostic and therapeutic options.

Quadruple WT GISTs comprise a small group with extremely heterogeneous background and molecular abnormalities but lacking mutations in all: KIT/PDGFRa/BRAF/ $R A S / S D H / N F 1$ genes $[24,25]$. But the genetic background is unclear, so we cannot predict GIST behavior, proliferation rate, malignant potential and/or response to targeted therapy.

It is possible to provide targeted therapy for most patients with KIT/PDGFRa positive GISTs with tyrosine kinase inhibitors, but response depends on KIT and PDGFRa gene mutational status [26]. Approximately $10 \%$ of patients have primary resistance and 50\% develop resistance through secondary mutations in the tyrosine-kinase receptor domain $[27,28]$ Although the modified genotype from secondary mutations may be associated with morphological and phenotypical changes in the tumor, resistance is caused not only by secondary mutation but also by other molecular mechanisms, including epigenetic mechanisms such as miRNAs [29]. Despite most GISTs being characterized by KIT/PDGFRa mutations, it is assumed that epigenetic alterations drive tumorigenesis in those GIST groups without any mutations.

Epigenetic GISTs changes may be responsible for poorer prognosis, treatment resistance, malignant potential and rapid proliferation, and also be associated with clinicalpathological parameters, tumour risk, mitotic index, tumour localization and size [30].

\section{Epigenetic mechanisms in normal and cancer tissue}

Epigenetic changes are non-sequential DNA alterations [31] and they result from the expression of specific transcription factors which are the main regulators of cell differentiation and crucial for normal development, maintenance of homeostasis and regulation and retention of tissue-specific gene expression [32]. Dysregulation of these signaling pathways and intercellular communication lead to altered gene features; especially in concrete gene silencing or increased gene expression resulting in initiation of tumorigenesis or diseases such as diabetes and auto-immune and mental disorders [32-34]. Epigenetic mechanisms are reversible and may be influenced by processes including breaks in DNA in utero and childhood development, environmental chemicals, drugs, diet and aging DNA $[35,36]$.

The key epigenetic mechanisms modifying DNA and chromatin are divided into 4 main categories: (1) covalent modification of DNA, principally through DNA methylation; (2) covalent post-translational histone modification including acetylation, methylation, phosphorylation, ubiqiutination and sumoylation [37]; (3) non-coding RNAs including microRNA, lincRNA and sncRNA [38] and (4) noncovalent mechanisms such as nucleosome remodeling and incorporation of histone variants [32, 39]. All epigenetic regulation and changes are mediated by epigenetic enzymes (EE) divided into the following three functional categories: writers (responsible for modifications); erasers (which remove modifications) and readers which recognize these modifications and direct them to the correct location [40].

EE's are further divided into groups defined by modification type: DNA methyltranferases (DNMTs), histone deacetylases (HDACs), histone acetyl transferases (HATs), protein/ histone methyltransferases (PMTs/HMTs), protein/histone demethylases (PDMs/HDMs), protein kinases, protein phosphatases and protein ubiquitin ligases (E3s) [40, 41]. Most enzymes function as oncogenes or tumor-suppressors able to trigger or inhibit tumorigenesis [42] and while they are alternative therapeutic intervention aims, development 
of functional inhibitors of these enzymes requires understanding their chemical mechanisms. Only three classes of enzyme inhibitors have reached clinical trial (DNMT inhibitors, HDAC inhibitors and Aurora-B kinases) and the DNMT and HDAC inhibitors are now approved by the Food and Drug Administration (FDA) [34]. Table 1 summarizes the main EE categories, their function in tumorigenesis and possible enzyme inhibition.

There is increasing evidence that mutations, deletions, internal methylation and other EE changes form the molecular basis of some tumor diseases [42, 43]. Many of these, including chromatin modifiers, exhibit mutations often leading to deregulation of DNA methylation throughout the genome [44]. Some mutations of genes responsible for EE are typical for certain types of tumor disease [42]. Yang et al. analyzed these epigenetic enzymes and their genes to determine if they share common signs of epigenetic deregulation across multiple types of tumor tissues, and they confirmed that many epigenetic enzymes are not only aberrantly expressed in the tumor but they also exhibit relatively universal features of deregulation in various types of tumors, including common correlation with global DNA methylation. They concluded that several hyper- and hypomethylation drivers and loci whose level of methylation correlated most with the drivers' expression were similar in various types of tumors [42]. This supports the finding that deregula- tion of DNA methylom is not directed by the type of tumor tissue and it also demonstrates universal epigenetic patterns of epigenetic deregulation [42].

\section{DNA methylation}

DNA methylation has a key role in the maintenance of genomic stability, development, imprinting and gene regulation. This results from direct chemical modification of the 5 'carbon of the cytosine pyrimidine ring, and this creates the 5-methylcytosine [45] in CpG islands [38] to which the methyl group is bound by a covalent bond to activate or silence genes [36, 46]. The methyl group donor is S-adenosyl methionine [37] and CpG islands are regions with remarkably high CG sequence frequency. Many CpG islands are clustered at the gene starting site and function in the promoter [47]. The methylation is then catalyzed by DNA methyltransferases (DNMTs, which include DNMT1, DNMT2, DNMT3A, DNMT3B and DNMT3L [48]. Chromosomal hyper/hypomethylation can also contribute to aberrant DNA methyltransferase expression [49] and this abnormal function then leads to malignant transformation $[50,51]$.

Abnormal DNA methylation plays a major role in carcinogenesis by silencing genes that are typically unmethylated, such as tumour suppressor genes and microRNAs [30, 52, 53]. While hypermethylation involves promoter $\mathrm{CpG}$ islands

Table 1. Epigenetic enzyme classes involved in tumorigenesis and types of their inhibitors.

\begin{tabular}{|c|c|c|}
\hline Enzyme class & Function in cancer & Inhibitor \\
\hline DNA methyltransferases & $\begin{array}{l}\text { They cause methylation in tumor tissue associated in particular } \\
\text { with the hypermethylation of CpG islands of tumor suppressor } \\
\text { genes, thus silencing them [174]. }\end{array}$ & $\begin{array}{l}\text { More in section: Epigenetic approach to the } \\
\text { treatment of GISTs }\end{array}$ \\
\hline Histone deacetylases & $\begin{array}{l}\text { They remove acetyl groups from histones, resulting in the forma- } \\
\text { tion of heterochromatin and the repression of transcription of } \\
\text { tumor suppressor genes associated with the carcinogenesis [41]. }\end{array}$ & $\begin{array}{l}\text { Two types and mechanisms of HDAC inhibi- } \\
\text { tors are currently known, both of them use for } \\
\text { inhibition zinc atom }[175,176] \text {. }\end{array}$ \\
\hline Histone acetyl transferases & $\begin{array}{l}\text { Involved in tumorigenesis, are considered to be tumor-suppressor, } \\
\text { but their disruption leads to an increase in tumor progression } \\
\text { [41]. }\end{array}$ & $\begin{array}{l}\text { More in section: Epigenetic approach to the } \\
\text { treatment of GISTs }\end{array}$ \\
\hline Protein/histone methyltransferases & $\begin{array}{l}\text { Lysine and arginine methyltranferases involved in tumorigenesis } \\
{[40] .}\end{array}$ & $\begin{array}{l}\text { Inhibitors have not yet demonstrated rel- } \\
\text { evance in vivo but in vitro several inhibitors } \\
\text { have been reported [41]. }\end{array}$ \\
\hline Protein/histone demethylases & $\begin{array}{l}\text { It has long been assumed that histones are methylated perma- } \\
\text { nently until the first demethylase was discovered [177]. However, } \\
\text { the role of lysine demethylase within of tumour biology has not } \\
\text { yet been elucidated [41]. }\end{array}$ & $\begin{array}{l}\text { The importance of their inhibitors using small } \\
\text { molecules has not yet been demonstrated [41]. }\end{array}$ \\
\hline Protein kinases & $\begin{array}{l}\text { Phosphorylation of histones in particular of serine } 10 \text { on histone } \\
3(\mathrm{H} 3 \mathrm{~S} 10) \text { is involved in tumor progression and cell division. Sev- } \\
\text { eral kinases have been identified that phosphorylate just H3S10 } \\
\text { histone, including Aurora 3-kinase, which is associated with more } \\
\text { types of tumors [178]. }\end{array}$ & $\begin{array}{l}\text { Some Aurora 3-kinase inhibitors have reached } \\
\text { the stage of clinical trials-phase II [41]. }\end{array}$ \\
\hline Protein phosphatases & $\begin{array}{l}\text { They provide dephosphorylation, which is also associated with } \\
\text { activation and inhibition of transcription. PP1 is identified as } \\
\text { antagonist to Aurora 3-kinase [179]. }\end{array}$ & - \\
\hline Protein ubiquitin ligases (E3s) & $\begin{array}{l}\text { Ligase MDM2 is oncoprotein that negatively regulates tumor } \\
\text { suppressor p53 through polyubiquitination and directs it to degra- } \\
\text { dation by proteosomes [180]. It is responsible for the modification } \\
\text { of H2ALys119 and H2BLys120. However, the association of these } \\
\text { modifications with cancer has not yet been clarified [41]. }\end{array}$ & - \\
\hline
\end{tabular}


in almost every cancer type, hypomethylation has been observed in repetitive sequences such as retro-transposons and heterochromatic DNA repeats [54, 55], which cover approximately $45 \%$ of the human genome [30]. Known repetitive sequences hypomethylated in cancer include LINE-1, Alu $Y b 8$ and Sat- $\alpha$ and NBL2 tandem DNA repeats [56].

\section{DNA hypomethylation in GISTs}

Although there have been few GIST methylation studies, aberrant gene expression in LINE-1 hypomethylation is reported in several tumor tissues [14, 57] and significant hypomethylation has been observed in high-risk GISTs, especially those with metastases. This correlates with increased chromosomal instability, losses-and-gains and malignancy and thus constitutes a marker for GIST risk assessment, aggression and poor prognosis [13, 14, 57]. We confirmed many more chromosome losses than gains; particularly loss of 14q, 22q, 15q, 1p and 9p [14]. The $1 p$ and 9p loss in LINE-1 hypomethylation was significantly pronounced in GISTs, with this inversely correlated with tumor size and mitotic index, and strong hypomethylation of Satellite $\alpha$ (Sat- $\alpha)$ and NBL2 tandem repeats also correlates with high-risk GISTs [14].

Recently described increased Endoglin (ENG) gene expression in KIT positive cells significantly correlates with increased risk of GIST malignancy, and this is attributed to KIT oncogenic mutant over-expression indirectly caused by DNA hypomethylation [58]. In contrast, PDGFRa mutated GISTs lack ENG expression thus causing thoughts about ENG expression linkage with KIT oncogenic signaling [58]. Although the machinations are not fully understood, ENG could serve as a novel therapeutic target in KIT positive GISTs, and this combined data reveals new possibilities in explaining GIST mechanisms and processes.

Haller et al. [59] also recorded SPP1 gene hypomethylation in GISTs [59]. SPP1 is significantly hypomethylated in a non-island $\mathrm{CpG}$ outside the promoter in patients with shorter survival, and it is considered a prognostic marker of GIST tumor malignancy in intermediary-risk groups [59]. SPP1 activates the key RAS/MAPK4 and PI3K/AKT signaling pathways which trigger oncogenesis by maintaining cell division, survival and metastases spread $[59,60]$. Increased SPP1 expression and hypomethylation potentially affect GIST proliferation [59].

However, GISTs exhibit mixed methylation depending on localization, mutational status, mitotic index and prognosis. Different methylation was demonstrated in PROM1/ CD131 and CD34 genes; with decreased methylation in KIT positive GISTs originating from the stomach and rectum and increased methylation in GISTs in the small intestine [59] Therefore, GIST epigenetic characteristics must differ depending on their anatomical location $[59,61]$, and these differences confirm the theory that at least four subpopulations of ICC cells give rise to distinct GISTs [62].

\section{DNA hypermethylation in GISTs}

There are also methylation studies of multiple genes in GISTs, with the CpG methylator phenotype(CIMP) providing simultaneous methylation of more than three genes in one sample [63]. House et al. [64] and Saito et al. [63] analyzed gene panels which had the combination of MGMT, hMLH1, p16, p73 and E-cadherin genes.

House et al. [64] analyzed promoter hypermethylation of the following eleven candidate genes involved in cancer development and progression; p16/INK4a, APC, MGMT, $h M L H 1, p 73, E$-cadherin, RAR-b, RASSF1A, RB, ER, and $D A P K$, and they found aberrant methylation of at least one gene in $84 \%$ of trials. The most methylated genes in descending order were: MGMT (47\%), p16 (45\%), RASSF1A (40\%), CDH1 (E-cadherin, 37\%), hMLH1 (34\%), and APC (31\%). Methylation of more than three promoters in one sample was found in $42 \%$ of GISTs [64]; and this supported the CpG island methylator phenotype theory (CIMP) [63]. The methylation of the following two promoters was predictive for disease recurrence and overall survival: hypermethylation of $\mathrm{CDH} 1$ which leads to loss of $E$-cadherin expression, and absence of $h M L H 1$ gene methylation [64].

$\mathrm{E}$-cadherin is the transmembrane protein product of the $\mathrm{CDH} 1$ tumour supressor gene; and the methylation that induces loss of E-cadherin function or expression is observed in epithelial to mesenchymal transition (EMT) throughout cancer onset $[45,65]$. This E-cadherin abnormality leads to elevated tumor cell invasiveness and consequent transition from benign to malignant disease in many cancers $[65$, 66]. We also published similar results in a cervical cancer study, where the $C D H 1$ gene expression was reduced in the progression of LSIL to HSIL depending on $\mathrm{CDH} 1$ methylation [67]. E-cadherin also functions in cell-cell adhesion and its repression in cancer cells results in cancer dissemination $[64,66]$.

Saito et al. [63] also published similar studies; where 8 of 9 aberrantly methylated $\mathrm{CpG}$ loci in many cancers were hypermethylated in GISTs [63]. The methylation levels were in the following descending order: $h M L H 1-60 \%$, MINT2 - 51\%, MGMT - 49\%, p73 - 49\%, p16 - 20\%, E-cadherin - 14\%, MINT1 - 9\%,p15 - 6\% and MINT31 - 0\% [63]. However, no correlation between CIMP and clinical-pathological parameters was confirmed [63], and although the methylation of the individual loci occurred equally in the KIT/PDGFRa positive GISTs, CIMP was observed in 100\% GISTs lacking mutations Although this lacked statistical significance [63], CIMPs and other genetic mechanisms including loss of heterozygosity and accumulation of MSI can contribute to transition from low to high-risk GIST.

GIST hypoxic conditions are characterized by loss of SDH complex function (SDHx) $[5,16]$ through mutation in one of its subunits or impaired promoter hypermethylation $[16,18]$. Killian et al. described DNA hypermethylation in SDHx deficient GISTs [68]. The SDHx WT GISTs is a group 
lacking SDHB protein and has no mutation in either of the SDH subunits. Moreover, SDHx hypermethylation does not appear to be caused by methyltransferase activity, but rather by failure to maintain DNA demethylation [68] because of the TET2 enzyme's inability to catalyze DNA demethylation [16]. Interestingly, while there are reported cases of GISTs with partial SDHC methylation and heterozygous mutation of the $S D H C$ gene $[68,69]$, partial $S D H C$ methylation is usually a marker for SDH complex inactivation through down-regulation of SDHC and consecutive loss of SDHB protein expression [69].

Hypermethylation not only correlates with localization and overall survival, but also with therapeutic response. It has been shown that KIT/PDGFRa gene mutations and deregulation of its signaling pathway are not responsible for development of resistance to sunitinib [70] which is the second line of treatment for imatinib resistant GISTs [26, 71]. There is also PTEN gene down-regulation in sunitinib resistant GIST cell lines and studies have revealed PTEN promoter hypermethylation in these cells [70]. Interestingly, PTEN gene down-regulation/inhibition has resulted in resistance in other tumor types $[72,73]$, and reduced PTEN gene expression in GISTs is associated with worse prognosis [74]. Further, down-regulated PTEN gene via promoter hypermethylation leads to Akt/mTOR activation and resistance to tyrosine kinase inhibitors [70].

The CDK4 inhibitor encoded by the CDKN2A ( $\left.p 16^{I N K 4}\right)$ gene and located at locus $9 \mathrm{p} 21$ is a further important protein accompanying many cellular physiological processes [75], and its alteration has also been described in GISTs [45]. However, there is no reported preference for a molecular change which deactivates $p 16^{\text {INK4 }}$ gene [75]. Patients with $p 16^{I N K 4}$ alteration had a worse prognosis $[75,76]$ and there- fore hypermethylated elimination of its function [76, 77] could have a role in GIST progression [78].

Perrone et al. [79] revealed concominant hypermethylation of the $\mathrm{p} 16^{\mathrm{INK} 4 \mathrm{a}}$ and $\mathrm{p} 14^{\mathrm{ARF}}$ promoters but only in small samples of GISTs [79], and p15 $5^{\mathrm{INK} 4 \mathrm{~b}}$ gene hypermethylation has also been demonstrated in GISTs. Further, all three tumor supressor genes are located in tandem at the same 1 9p21 locus, and this could provide a useful biomarker for risk assessment and new treatment options [79]. A genome-wide DNA methylation analysis also revealed that hypermethylation of the three REC8, p16, PAX3 genes is strongly associated with GISTs aggressiveness and poor prognosis, and $R E C 8$ and PAX3 appear to be methylated with some divergence in small and malignant GISTs $[14,80]$.

While He et al. [48] reported expression of all DNMT types except DNMT3A in their DNMT and MBD2 expression study, the methyl-CpG-binding domain protein 2 encoded by the $M B D 2$ gene was a transcriptional repressor silencing the gene [48], and he found MBD2 protein expression significantly higher in GISTs. Elevated levels of DNMT and MBD2 expression levels are considered to promote GISTs progression through hypermethylation induced inactivation of tumor supressor genes [48]. Finally, an overview of the most common genes affected by aberrant methylation in GISTs is summarized in Table 2.

\section{Histone modification}

Histone modification affects gene expression through 'histone marks' which serve as binding sites for proteins involved in chromatin structure control and polymerases' ability to initiate replication, transcription, DNA repair [30] and recruitment of other proteins with those functions [37,

Table 2. An overview of the most common genes affected by aberrant methylation in GISTs.

\begin{tabular}{|c|c|c|c|c|}
\hline Genes & Status & Function & Prognosis & References \\
\hline$p 16^{I N K 4}$ & Hypermethylated & $\begin{array}{l}\text { Cyclin-dependent kinase inhibitor, cell cycle } \\
\text { regulating gene }\end{array}$ & Worse prognosis & {$[49,75]$} \\
\hline REC8 & Hypermethylated & Function in meiotic recombination & Aggressiveness & {$[80]^{*}$} \\
\hline$P A X 3$ & Hypermethylated & Control of gene expression & Poor prognosis & {$[80]^{*}$} \\
\hline$M B D 2$ & Hypermethylated & Transcriptional repressor, gene silencing & Tumor progression & [48] \\
\hline $\begin{array}{l}\text { LINE-1 } \\
\text { (Sat- } \alpha \text { and NBL2) }\end{array}$ & $\begin{array}{l}\text { Hypomethylated (similar } \\
\text { strong hypomethylation) }\end{array}$ & $\begin{array}{l}\text { Repetitive sequence, transposable elements, } \\
\text { tandem repeats }\end{array}$ & $\begin{array}{l}\text { High risk GISTs, poor prognosis, } \\
\text { aggressiveness }\end{array}$ & {$[14,57]$} \\
\hline SPP1 & $\begin{array}{l}\text { Newly discovered hypo- } \\
\text { methylation }\end{array}$ & $\begin{array}{l}\text { Involved in the attachment of osteoclasts to the } \\
\text { mineralized bone matrix, cytokine }\end{array}$ & Shorter survival & {$[59]^{*}$} \\
\hline PTEN & Hypermethylated & Tumour suppressor & $\begin{array}{l}\text { Worse prognosis, resistance to tyro- } \\
\text { sine kinase inhibitors }\end{array}$ & {$[70]^{*}$} \\
\hline$S D H x$ & Hypermethylated & $\begin{array}{l}\text { Participating in Krebs cycle and involved in the } \\
\text { respiratory chain }\end{array}$ & 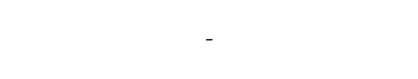 & {$[17,18,69]$} \\
\hline $\mathrm{CDH1}$ & Hypermethylated & $\begin{array}{l}\text { Tumor suppressor, cell-cell adhesion, function } \\
\text { in EMT }\end{array}$ & $\begin{array}{l}\text { Worse prognosis, transition from } \\
\text { benign to malignant }\end{array}$ & {$[65-67]$} \\
\hline$h M L H 1$ & Hypomethylated & Tumor suppressor, DNA mismatch repair gene & Disease recurrence & {$[64]^{*}$} \\
\hline
\end{tabular}

* http://www.genecards.org/ 
81]. Histone modification proceeds through histone 'tails' [82] including acetylation, methylation, phosphorylation, ubiquitination and sumoylation $[37,83]$.

For example, reversible lysine acetylation/deacetylation is related to the accessibility of chromatin for transcription, replication and repair, and it is well-known that transcriptional active euchromatin is hyperacetylated [84]. These processes are catalyzed by histone acetyltransferases (HATs) and histone deacetylases (HDACs) [82]. In contrast lysine methylation prevents acetylation and silences gene activation depending on mono-di-or-tri- methyl methylation groups. Further, lysine 9 and 27 methylation on histone H3 $\left(\mathrm{H} 3 \mathrm{~K}_{2} 2 \mathrm{Me}^{2}, \mathrm{H} 3 \mathrm{~K} 27 \mathrm{Me}^{3}\right)$ provides sign of gene inhibition; and gene repression is mediated by HOTAIR lincRNA binding to the PRC2 methyltransferase complex that trimethylates specific genes' H3K27 and thus suppresses them [14, 82].

While lysine 9 and 13 acetylation occurs on histone $\mathrm{H} 3$, the trimethylation of lysine 4 and phosphorylation of serine 10 on this histone are characteristic for euchromatin $[30,85]$. In contrast, the transcription sites of many genes in the HOX cluster are significantly enriched in malignant GISTs by the $\mathrm{H} 3 \mathrm{~K}_{4} \mathrm{Me}^{2} / \mathrm{H} 3 \mathrm{~K}_{4} \mathrm{Me}^{3}$ epigenetic marks $[32,86]$ which indicate active genes capable of over-expression in the respective genes [87].

In addition, $\mathrm{H} 2 \mathrm{AX}$ histone, a variant of the $\mathrm{H} 2 \mathrm{~A}$ core histone, is involved in GIST regulation through its action as the main regulator of cellular response to DNA damage, and this therefore has a role in the cell death witnessed in cytotoxic therapy [88]. Recognition of DNA damage is not direct, but mediated through interaction with proteins that recognize phosphorylated $\mathrm{H} 2 \mathrm{AX}$, because $\mathrm{H} 2 \mathrm{AX}$ is rapidly phosphorylated in serine residues in response to DNA damage [89]. Liu [88] discovered that while this variant is down-regulated in untreated GISTs via the PI3K and $m T O R$ signal pathways, its up-regulation increases cell sensitivity to cytotoxic drugs and thus correlates with GIST sensitivity to imatinib. This provides great therapeutic potential in imatinib resistant GISTs for several reasons [88]; including the fact that $P I 3 K$ down-regulation can result in increased H2AX expression which counteracts PI3K's normal function of anti-apoptosis.

\section{“Oncomirs”}

Recent studies report that many deregulated miRNAs are involved in tumorigenesis development, prognosis and invasion or contribute to drug resistance [87, 90, 91]. Depending on their target and expression level in a variety of cancers, these act as either oncogenes or tumor suppressors $[61,90]$. This function is reversible; where they can function as a tumour suppressor if their target is oncogene and as an oncogene if their target is a suppressor [92].

MiRNAs are a highly conserved group of short non-coding RNAs with 19-24 nucleotides and they are part of development, differentiation, cell proliferation and apoptosis $[12$,
30, 90, 91]. More precisely, they influence gene control post-transcriptionally by inducing translational inhibition or direct destabilization of the target mRNA [30, 90]. This regulation is mediated through base pairing of the seed region 6-8 nucleotides [93] which are partly complementary sites [93] at the 5' end of the miRNA and $3^{\prime}$-untranslated region (3'UTR) of target mRNA [87, 90].

MiRNAs linked to oncogenesis are often referred to as "oncomirs" [30].

Individual miRNAs can be controlled by other miRNAs as part of miRNA clusters, and this highlights the complexity of miRNA interactions in cancer studies [94]. Cluster theory supports the existence of the $5 \mathrm{miR}-15 \mathrm{a} / 16, \mathrm{miR} 17 / 20$, miR-221/222, let-7 and miR-34 clusters which regulate cell cycle progression by directly targeting cell cycle regulators [92].

Oncogenic miRNAs can trigger, affect, and cause tumour progression by targeting cyclin-dependent kinase inhibitors, while tumor suppressor miRNAs stop the cell cycle by reducing the regulation of many cell cycle components [92]. MiRNAs also co-operate with p53, E2F and c-MYC transcription factors involved in cell cycle regulation, and while they enhance the function of these transcription factors, they also prevent prior over-translation of cell cycle proteins in response to mitogenic and oncogenic signals; thereby protecting the cell from excessive and uncontrollable replication [95].

Although the mechanisms underlying miRNA deregulation in malignancies are not fully understood, studies have shown that miRNA silencing is closely linked to epigenetic mechanisms involving DNA methylation and histone modification [12]. This hypothesis is confirmed by treatment with DNA methyltransferases (DNMTs) and histone deacetylase inhibitors (HDACis) which renew the expression of multiple miRNAs in tumor cells $[12,87]$. The miRBase (http://www.mirbase.org/) records 1,881 miRNA precursors and 2,588 mature miRNAs $[96,97]$, and certain miRNAs have been described in gastrointestinal stromal tumors [61, 98]. Up-regulated miRNAs in GISTs are associated with the loss of $14 \mathrm{q}$, tumor localization and risk level [61]. For example, while miR-196a over-expresion is strongly connected to malignant behavior [87], miR-137 and miR-218 down-regulation is reported in GISTs $[99,100]$.

The first mention of deregulated miRNAs in GISTs was published by Subramanian et al. in 2008 [101]. Their research comparing GISTs with other cancers identified 16 over-expressed and 10 under-expressed miRNAs in GISTs [101]. In addition, miR-221 and 222 were the first variablyregulated miRNAs discovered during melanoma erythropoiesis and progression, and their up-regulation is observed in the following malignancies: glioblastoma, hepatocellular carcinoma and pancreatic and prostate cancer $[102,103]$.

However, it must be stressed that these miRNAs are surprisingly significantly down-regulated in GISTs and have therefore been classified as oncogenic miRNAs [11]. 
Divergence in miR221/222 expression in GISTs and other sarcomas can either be explained by their different function in GISTs or it remains unclear whether these miRNAs have the same target in GISTs $[11,90,98]$. Although no correlation was found between under-expressed miR-221/222 and proliferation rate or KIT-mutation status and tumourrisk grading, the massive repression of both miRNAs was demonstrated in KIT-positive GISTs compared to normal tissue $[30,98]$. These results suggested that miR221/222 down-regulation in GISTs is associated with significant KIT expression [98].

In their 2013 studies with the luciferase enzyme, Gits et al.[11] showed that KIT gene silencing via miRNA-mediated inibition is more likely through translational repression than by degradation of target mRNA [11]. This theory is confirmed by the significant decrease of KIT protein and less notable mRNA decline [11]. Similarly, KIT supression via miR-221 and 222 resulting in silencing active AKT [90] is supported by $A K T$ gene down-stream localization in pathways associated with GISTs transformation [104]. Nevertheless, in vitro studies on the GIST-T1, GIST48 and GIST882 cell lines have demonstrated the capacity to reduce cell vitality and induce apoptosis in all cell lines regardless of mutational status $[11,90]$. In addition, the molecular apoptotic mechanisms involving the AKT protein, pro-apoptotic proteins and the BCL2 pro-survival protein also appear regulated by miR-221/222. Under normal conditions, the AKT protein regulates cell survival by blocking the pro-apoptotic protein while BCL2 inhibits apoptosis [105].

Ihle et al. [90] used this knowledge to link miR-221/222 expression with GIST apoptotic events. Their results revealed that miR-221/222 over-expression led to BCL2 down-regulation, and the fact that miR-222 directly targets KIT suggests these miRNAa modulate KIT in GIST $[11,30,98]$. Therefore, although miR221 and 222 do not affect diagnostics, they appear appropriate tools for GIST treatment; especially in elucidation of GIST secondary resistance to tyrosine-kinse inhibitors [98].

The CDKN1B and CDKN1C cell cycle inhibitors provide further predicted miR-221/222 targets [61]. These function as negative cell cycle regulators in normal conditions, controlling the cycle in the $G 1$ phase, and hence cell division (Gene ID: 1026) [106]. Down-regulated $C D K N 1 B / C$ correlates with increased miR-221/222 expression in GISTs with higher mitotic index [61], and miR-221/222 CDKN1B/C inhibition increases cell division [61]. Haller et al. [61] found co-expression of multiple miRNAs localized at the same $14 \mathrm{q}$ chromosomal site and reported that $14 \mathrm{q}$ loss was the most common chromosomal aberration in GISTs [56, 61, 107]. Reduced miR-134 and miR-370 expression localized at $14 \mathrm{q} 32.31$ in GISTs are also associated with tumor risk and progression and shorter survival [61], and since these share poor complementarity with the target mRNAs [108], it is assumed that regulation is more through translation inhibition than direct mRNA degradation. Hence, down-regulation of these
miRNAs leads to elevated aberrant mRNA translation and increased risk of progression [61].

Similar to the miR-221/222 cluster, the miR-17-92 cluster, including miR-17, 18a, 19a/b and 20a, has lower expression in GISTs than in leiomyosarcomas [11]. This cluster has notorious oncogenic potential in tumors such as gastric and colon cancers and neuroblastoma [11, 109]. It is believed to regulate KIT/ETV1 gene [11], and miR-17/20a is responsible for the most significant changes in GIST expression [11]. While miR-222 directly targets KIT, miR-17/20a does not, but it appears to down-regulate other target genes. This is strongly contrasted to Gits et al's finding [11] that miR-17/20a directly targets ETV1, but that miR-222 degrades ETV1 protein levels through additional target genes $[10,11]$. Surprisingly, it was even confirmed that PDGFRa mRNA contains the putative binding site for miR-17/20a which can also influence PDGFRa GISTs [11]. In addition, the other down-regulated members of the miR-17-92 cluster in GISTs have similar action; miR-18a has potential effect on KIT and miR-19a/b on ETV1 [11].

Kim et al. [110] report opposing connection between KIT and miR-494 expression, where over-expressed miR-494 directly eliminated KIT, including the $p-A K T$ and $p-S T A T$ expression levels. This regulation is mediated through several KIT mRNA seed-match sites, and the miRNA-494 inhibition induced KIT over-expression. The authors therefore concluded that miRNA is the key modulator of KIT expression in GISTs. It is also likely that miR-494 transfection has similar effect on GISTs as the tyrosine-kinase inhibitor, thus making it an important therapeutic target [110]. miR-218 is also well known to be down-regulated and have tumor suppressive properties [111-113], and it directly affects GISTs as a negative regulator of the KIT gene [100]. It is generally underexpressed in GISTs, so increased expression leads to downregulated KIT expression, reduced cell division and tumor cell viability and increased apoptosis [100]. Future treatment, therefore, could be based on miR-218 over-expression.

However, it is not only genes that are epigenetically regulated, miRNAs can also be targeted for GIST epigenetical silencing. While miR-335 has oncogenic function in glioma and gastric and lung cancers [12, 114, 115], Isosaka et al.[12] were the first to report that miR-34a and miR-335 are targets of epigenetic events and suppress GIST development [12]. These genes are usually silenced by DNA methylation and this deregulation results in GIST oncogenesis. This hypothesis is confirmed by recovery of miR-34a/miR-335 expression and restoration of their tumour suppressor activity [12], and it makes them excellent targets for anticancer therapy using DNA methyltransferase inhibitors [12,87].

Research into miRNA activity in GISTs increasingly reveals their association with the following histo-morphological features: the mutational status of KIT/PDGFRa genes, localization, degree of risk, chromosomal aberration and especially the $14 \mathrm{q}$ loss $[56,61,87]$ and response to treatment with imatinib tyrosine kinase inhibition [29]. 
Here, miR-125a-5p correlates with KIT mutationl status and metastasis, it is responsible for imatinib accessibility [29], and it is another miRNA which affects oncological processes by inducing aggressiveness, resistance to tyrosin kinase inhibitors and worse survival rates $[116,117]$. Its function in different types of tumor depends on cell type [29, 118].

The intended tmiR-125a-5p target gene, PTPN18, is involved in many cellular processes, including phosphorylation and regulation of the cell cycle and anti-apoptotic proteins. PTPN18 is also involved in rebuilding the cytoplasmic microscopic network of actin filaments which may explain imatinib resistant GIST morphological changes $[29,119]$. The protein encoded by PTPN18 is a member of the protein tyrosine phosphatase (PTP) family [120] which is strongly expressed in cancer [121]. This protein can knock-out enhanced autophosphorylated tyrosine kinases that are up-regulated in tumor tissues [120, 121]. Takahashi et al. [122] also recorded that deregulated tyrosine kinase phosphorylation influences imatinib resistance in GISTs in a substitute manner [122], thus providing phosphatase involvement in GIST imatinib resistance [29]. While secondary mutations cause imatinib resistance in GISTs, reports also reveal imatinib resistant GISTs with only one KIT mutation $[27,29]$. These combined results confirm that miR-125a-5p regulation of PTPN18 protein and their joint involvement in imatinib resistance is an alternative to secondary KIT mutations in GISTs [29].

Akçakaya [29] then described that miR-150-3p and miR-301a-3p correlated with metastasis and both were up-regulated in other tumor types [123], and he identified that miR-1915 was closely associated with metastasis and two KIT mutations; making it a suitable marker for the survival of GIST patients undergoing tyrosine kinase inhibitor treatment [29].

Further, miR-21 regulation of imatinib response has also been analyzed in GISTs. Similar to miR-221/222, this affects sensitivity by regulating of expression of the $\mathrm{Bcl}-2$ gene [124] which inhibits apoptosis [105, 125]. Although miR-21 is under-expressed in GISTs, increased expression decreases regulated $\mathrm{Bcl}-2$ expression, and miR-21 therefore has possible roles as GIST tumour suppressor and potential therapy biomarker [124].

Gao [126] found that miR-320a is also resistant to imatinib and regulates apoptotic pathways This is down-regulated in imatinib-resistant GISTs and the under-expression correlates with the short period of time after treatment starts before imatinib resistance begins. This miR has multiple target genes involved in drug resistance and apoptosis [127] so down-regulated miR-320a could be responsible for GIST resistance to imatinib by suppressing the GIST cell apoptotic pathway [126]. However, research in this area is still required.

MiRNAs also contribute to epithelial-mesenchymal transition, and Liu et al. [99] discovered that miR-137 encouraged EMT-repressed GIST expression through its direct Twist1 target gene which is the key EMT regulator. Twist1 also down-regulates E-cadherin, another EMT-related gene
[128], and Twist1 over-expression decreases E-cadherin expression $[128,129,130]$. Although MiR-137 is downregulated in GISTs, experimental over-expression led to GIST cell cycle inhibition and induced apoptosis [99], thus confirming miR-137 function as a tumour suppressor [99, 131, 132]. Increased miR-137 expression correlates with increased E-cadherin regulation which enables GIST cells to remain in the epithelial morphology [99]. These claims are confirmed in the recent E-cadherin study [133] where miR-137 was significantly dysregulated, and decreased E-cadherin expression correlated with GIST metastases development This makes miR-137 an excellent candidate for targeted therapy.

Tumor cell SDH complexes can be influenced by miRNAs which prefer hypoxic conditions. MicroRNA miR-210 is over-expressed in many malignancies and Tsang et al. [134] analysed its function in SDH-deficient GISTs; specifically, the KIT/PDGFRa/SDHB negative $S D H B^{\mathrm{IHC}-}$. This GIST type most likely originates by SDH complex abnormality rather than by kinase activation [134]. miR-210 is a key regulator in the response to SDH hypoxic function [135] and it is significantly over-expressed in SDHB ${ }^{\mathrm{IHC}-}$ GISTS compared to $S D H B^{\mathrm{IHC}+}$ and this leads to hypoxic gene expression [134]. The relationship of these two markers and their deregulating mechanisms require further study, and this could substantially benefit by focusing on the HIF $\alpha$ transcriptional regulator of cellular and developmental response to hypoxia [135-137] whose over-expression in GIST is associated with metastases and worse survival rate $[138,139]$.

Up-regulated miR-196a effect is similar to that of the previously-mentioned RNAs and this is observed in gastric, pancreatic, cervical and lung tumors [140, 141] where it is associated with poor prognosis, metastases and highgrade risk [87, 140]. In contrast, miR-196a acts as a tumor suppressor in melanoma and breast cancer [140, 142] and Ninuma et al. [87] record that although miR-196a and HOXC genes are up-regulated in malignant GISTs, the inhibition of over-expressed miR-196a results in suppression of malignant potential [87]. miR-196a can therefore be an appropriate marker of risk degree and a novel therapeutic target; similar to lincRNA and HOTAIR, [87, 143].

LincRNA is a long intergenic non-coding RNA encoded by HOTAIR and present in the HOXC genes cluster which controls gene expression [87, 144]. Up-regulation of the HOTAIR oncogenic factor has been observed in GISTs and other cancers [144], where it is related to aggressiveness and metastatic invasion $[87,145]$ However, prevention of deregulated HOTAIR expression leads to suppressed cell invasion [87]. Meanwhile, lincRNA represses its targets genes directly by interaction with the histone modifying complex [144].

There is scant information on miRNAs whose expression correlates directly with localization and mutation status in GISTS, and it remained unknown if differential expression could determine clinical-pathological differences in GISTs. Haller et al [61] identified miR-193A-3p and miR-151-5p 
which are associated with localization and mutations and is targeted to the KIT gene; both were down-regulated in KIT-positive GISTs. They also found the over-expression of miR-7-1 and miR-598 targeted to the PDGFa ligand of the PDGFRa receptor in gastric GISTs, while miR-329 was up-regulated in intestinal GISTs [61].

Moreover, Yamamoto [146] confirmed that miR-133b down-regulation was directly related to FASCIN1 overexpression, and this is thought to not only contribute to aggressiveness and shorter survival and also to significantly correlate with clinical-pathological features, tumor size, mitotic index and metastases spread.

Other miRNAs responsible for GISTs malignancy include the IGF1R-miR-139-5p/ miR-455-5p/ let-7b regulatory network, and this network most likely contributes to the effect on KIT/PDGFRa WT-SDH deficient GISTs through epigenetic IGF1R expression. Moreover, Pantaleo et al [147] consider that the epigenetically regulated IGF1R over-expression in KIT/PDGFRa WT-SDH deficient GISTs is similar to oncogenic KIT/PDGFRa mutations. Finally, all additional RNAs involved in GISTs tumorigenesis are listed in Table 3.

\section{The epigenetic approach to GIST treatment}

Epigenetic mechanisms can aid disease prediction and prognosis [64] because alterations made by these mechanisms can be recovered by epigenetic therapy [32]. This therapy is based on treating disease by delivering epigenome-influencing techniques appropriate for the particular circumstances. miRNA's involved in tumor disease must meet strict criteria to be ideal therapeutic tools, and the discovery of miRNA involvement in carcinogenesis now offers new mechanisms of action and new treatment options [148, 149]. The two methods for treating deregulated miRNAs in tumour tissue are through miR analogues and antagonists

Analogues are used in loss of miRNA function [149]. Their intervention is by "miR replacement therapy" which substitutes for aberrant miRNA and compensates for the damaged function. This restores normal cell processes by replacement of abberant tumour suppressor miRNAs [150]. In contrast, miRNA antagonists inhibit functionally overexpressed miRNA; and especially oncogenic miRNAs. This method relies on the introduction of a chemically modified RNA which binds to the deregulated miRNA [151, 152], but its main disadvantage is that the antagonist may bind non-specifically to other RNAs and result in undesirable side effects [149].

The main obstacle to the use of miRNAs as promising therapeutic targets is pharmacokinetics because this determines all factors involved in transport of the unaltered miRNA to the target site, and it must ensure effective and safe delivery of the therapeutic miRNA to the cell [148, $149,153]$. Both local and systemic delivery are important because both have limitations and side effects $[148,154]$; and a vector based system such as atelocollagen [148, 155] or a neutral lipid emulsion could serve as appropriate miRNA transporters [154]. These different delivery systems have individual bio-distribution pathways and the correct choice of delivery system depends on the type of tumor, and this

Table 3. Other altered microRNAs in GISTs.

\begin{tabular}{|c|c|c|c|c|}
\hline MicroRNA & Status & Function & Prognosis & References \\
\hline miR-24-1 & - & High expression in gastric GISTs & - & [61] \\
\hline miR-132 & Mutation dependent & Higher expression in gastric PDGFRa mutated GISTs & - & [61] \\
\hline miR-134 & $\begin{array}{l}\text { Chromosomal } \\
\text { location associated }\end{array}$ & Lower expression in GISTs with $14 \mathrm{q}$ loss & $\begin{array}{l}\text { Tumor progression/ } \\
\text { shorter survival }\end{array}$ & [61] \\
\hline miR-135b & - & $\begin{array}{l}\text { Regulator of KIT gene, associated with development } \\
\text { of GISTs }\end{array}$ & - & [181] \\
\hline miR-136 & Upregulated & $\begin{array}{l}\text { Upregulation in small bowel GISTs in the high-risk } \\
\text { group with } 14 \mathrm{q} \text { loss }\end{array}$ & - & [182] \\
\hline $\operatorname{miR}-150$ & - & Low expression in the intestinal GISTs & - & {$[61]$} \\
\hline miR-342 & $\begin{array}{l}\text { Downregulated in } \\
\text { high risk GISTs }\end{array}$ & Targets: ELK1, TRAF2, CDC42 & - & [182] \\
\hline $\operatorname{miR}-370$ & $\begin{array}{l}\text { Chromosomal } \\
\text { location associated }\end{array}$ & Lower expression in GISTs with $14 \mathrm{q}$ loss & $\begin{array}{l}\text { Tumor progression/ } \\
\text { shorter survival }\end{array}$ & [61] \\
\hline miR-409-3p & Upregulated & $\begin{array}{l}\text { Upregulation in small bowel GISTs in the high-risk } \\
\text { group with } 14 \mathrm{q} \text { loss }\end{array}$ & - & [182] \\
\hline miR-504 & $\begin{array}{l}\text { Localization } \\
\text { dependent expression }\end{array}$ & Higher expression in gastric KIT mutated GISTs & - & [61] \\
\hline miR-625 & Downregulated & $\begin{array}{l}\text { Downregulation in small bowel GISTs in the high- } \\
\text { risk group with } 14 \mathrm{q} \text { loss }\end{array}$ & - & [182] \\
\hline miR-638 & Downregulated & $\begin{array}{l}\text { Downregulation in small bowel GISTs in the high- } \\
\text { risk group with } 14 \mathrm{q} \text { loss }\end{array}$ & - & [182] \\
\hline
\end{tabular}


choice strongly affects successful treatment [148]. Therefore, laboratories face the challenge of creating a delivery system that will ensure stability, safety and increased pharmaceutical uptake by target tissue cells [149].

Unfortunately, miRNA-based therapeutics is still in its infancy and few studies have considered pre-clinical development. Most of the previously mentioned miRNAs have great therapeutic potential [156] and if these treatments become available then targeted therapy with miR-17-92 and miR-221/222 cluster members can significantly suppress KIT/ETV1 levels [11, 150].

Methylation can be therapeutically affected via DNMT inhibitors (DNMTi), and 5-azacytidine and 5-aza-2-deoxycytidine have been approved by FDA for treatment of myelodysplastic syndrome (MDS) and acute myeloid leukemia (AML) $[157,158]$. Clinical trials were performed for several solid tumours [88], and it was recorded that both DNMT inhibitors are highly toxic cytosine analogs phosphorylated after entry into the cell and incorporated in DNA to block methylation [159]. Inhibitors form complexes with DNMTs reducing the methylation of CpG islands [160] and their function is more pronounced at lower concentrations because otherwise it encroaches on DNA synthesis and causes DNA damage $[161,162]$. In contrast, non-nucleoside DNMT inhibitors have lower cytotoxicity because they do not require inclusion in DNA [159], and they have been developed for use in solid tumours for their potential ability to induce hypomethylation $[159,163]$; but they have limited activity in living cells [163].

While 5-aza-2-deoxycytidine has been shown to be more potent in inhibiting methylation and has the ability to restore the function of silenced genes in cancer cells compared to non-nucleoside inhibitors [164], the efficacy of DNMTi and histone deacetylase inhibitors (HDACi) treatment is moderately limited in solid tumours. The reasons for this are not fully known, but DNMTi and HDACi are relatively unstable $[161,165]$ and this instability in less pervious solid tumours presents a problem [165]. In addition, HDACi are not sufficiently selective or target-specific in solid tumours [165], but the key differences in the treatment of haematological malignancies and solid tumour are strong vascularization in solid tumours, the hypoxia and different epigenetic profiles of hypoxic tumor cells and also the tumor micro-environment [166]. Moreover, hypoxia in solid tumors is greater than in haematology malignancy and is associated with increased aggressiveness and tumor resistance [166].

However, treatment of GISTs by HDACi and the Notch pathway anti-tumor effect have been described despite these limitations. Notch is a negative regulator of KIT signaling [167], and although constitutively-active Notch leads to growth restraint independent of KIT mutations or sensibility to tyrosine kinase inhibitors, Notch mRNA is very low in GISTs. Notch regulation and expression can be increased by the suberoylanilide hydroxamic acid (SAHA) dosedependent histone deacetylase (HDAC) inhibitor. This is also approved by the FDA $[167,168]$ and it should lead to apoptosis and silencing of KIT activation.

HDAC inhibitor (HDACi) treatment re-activates silenced tumor supressor genes and increases acetylation as antitumor factors leading to growth arrest, cellular differentiation and apoptosis [81, 169]. Muhlenberg et al. [167] first demonstrated strong HDACi anti-proliferative and pro-apoptotic function in both imatinib positive/sensitive GISTs and imatinib negative/resistant GISTs [170]. Hence, the active form of HDACi has GIST growth inhibitory function.

There are several possible methods of SAHA KIT repression in GISTs. The first is interaction of SAHA with KIT protein chaperone Hsp90 and maintenance of its hyperacetylation [167, 170, 171]. Hsp90 helps KIT protein to fold into a functional structure and stabilizes it in that form, and moreover it is important in KIT activation $[170,172]$. The second method is mediated through reduction of KIT mRNA [167, 171]. In experimental studies, the HDACis LBH589 (panobinostat) and SAHA (vorinostat) exhibit the highest potential of the tested valproic acid, trichostatin A, NaButyrate, LBH589 and SAHA alternatives [167]. It is also necessary here to include pharmaceuticals focused on histone acetyltranferase (HAT) [169]; especially the selective HAT inhibitor C646 which inhibits GISTs proliferation of depressed ETV1 protein and makes KIT signaling ineffective [173].

\section{Conclusion}

Herein we reported the main basic and known epigenetic mechanisms as alternatives to mutations in KIT/PDGFRa/ $B R A F / S D H x$ and other genes in GISTs. Many studies and conclusions confirm that processes, such as DNA/chromatin methylation, chromatin remodeling and packaging and non-coding miRNAs have the same role as the genome in regulating biological processes and tumor formation and progression. Moreover, better understanding of epigenetic mechanisms can provide precise knowledge on how they affect cells and it can also identify new potential oncogenes and tumor supressor genes regulated by epigenetic intervention. Finally, epigenetics can reveal new therapeutic targets for successful treatment of resistant and metastatic GISTs.

Acknowledgements: This work was supported by Slovak Research and Development Agency Projest No. APVV-14-0273 and by the "Biomedical Center Martin" ITMS code: 26220220187; the project is co-financed from EU resources.

\section{References}

[1] PLANK L, BUZALKOVA V, SZEPE P, LASABOVA Z, JASEK $\mathrm{K}$ et al. Gastrointestinal stromal tumor after tyrosine kinase inhibition therapy: a review of biopsies of 34 patients with clinically suspected relapse and/or progression of the tumor. Neoplasma 2017; 64: 464-473. https://doi.org/10.4149/ neo_2017_319 
[2] MINARIK G, PLANK L, LASABOVA Z, SZEMES T, BURJANIVOVA $T$ et al. Spectrum of mutations in gastrointestinal stromal tumor patients - a population-based study from Slovakia. APMIS 2013; 121: 539-548. https://doi.org/10.1111/ apm.12019

[3] XU Z, HUO X, TANG C, YE H, NANDAKUMAR V et al. Frequent KIT mutations in human gastrointestinal stromal tumors. Sci Rep 2014; 4: 5907. https://doi.org/10.1038/ srep05907

[4] TSUIMURA T, MAKIISHI-SHIMOBAYASHI C, LUNDKVIST J, LENDAHL U, NAKASHO K et al. Expression of the intermediate filament nestin in gastrointestinal stromal tumors and interstitial cells of Cajal. Am J Pathol 2001; 158: 817-823. https://doi.org/10.1016/S0002-9440(10)64029-1

[5] RAVEGNINI G, NANNINI M, SAMMARINI G, ASTOLFI A, BIASCO G et al. Personalized Medicine in Gastrointestinal Stromal Tumor (GIST): Clinical Implications of the Somatic and Germline DNA Analysis. Int J Mol Sci 2015; 16 : 15592-15608. https://doi.org/10.3390/ijms160715592

[6] JOENSUU H, RUTKOWSKI P, NISHIDA T, STEIGEN SE, BRABEC $P$ et al. KIT and PDGFRA mutations and the risk of GI stromal tumor recurrence. J Clin Oncol 2015; 33: 634642. https://doi.org/10.1200/JCO.2014.57.4970

[7] JASEK K, BUZALKOVA V, MINARIK G, STANCLOVA A, SZEPE P et al. Detection of mutations in the BRAF gene in patients with KIT and PDGFRA wild-type gastrointestinal stromal tumors. Virchows Arch 2017; 470: 29-36. https:// doi.org/10.1007/s00428-016-2044-4

[8] BRAHMI M, ALBERTI L, DUFRESNE A, RAY-COQUARD I, CASSIER P et al. KIT exon 10 variant (c.1621 A > C) single nucleotide polymorphism as predictor of GIST patient outcome. BMC Cancer 2015; 15: 780. https://doi.org/10.1186/ s12885-015-1817-5

[9] JANEWAY KA, KIM SY, LODISH M, NOSÉ V, RUSTIN P et al. Defects in succinate dehydrogenase in gastrointestinal stromal tumors lacking KIT and PDGFRA mutations. Proc Natl Acad Sci U S A 2011; 108: 314-318. https://doi. org/10.1073/pnas.1009199108

[10] CHI P, CHEN Y, ZHANG L, GUO X, WONGVIPAT J et al. ETV1 is a lineage survival factor that cooperates with KIT in gastrointestinal stromal tumours. Nature 2010; 467: 849853. https://doi.org/10.1038/nature09409

[11] GITS CM, VAN KUIJK PF, JONKERS MB, BOERSMA AW, VAN IJCKEN WF et al. MiR-17-92 and miR-221/222 cluster members target KIT and ETV1 in human gastrointestinal stromal tumours. Br J Cancer 2013; 109: 1625-1635. https:// doi.org/10.1038/bjc.2013.483

[12] ISOSAKA M, NIINUMA T, NOJIMA M, KAI M, YAMAMOTO E et al. A Screen for Epigenetically Silenced microRNA Genes in Gastrointestinal Stromal Tumors. PLoS One 2015; 10: e0133754. https://doi.org/10.1371/journal. pone. 0133754

[13] WOZNIAK A, SCIOT R, GUILLOU L, PAUWELS P, WASAG $\mathrm{B}$ et al. Array CGH analysis in primary gastrointestinal stromal tumors: cytogenetic profile correlates with anatomic site and tumor aggressiveness, irrespective of mutational status. Genes Chromosomes Cancer 2007; 46: 261-276. https://doi. org/10.1002/gcc.20408
[14] IGARASHI S, SUZUKI H, NIINUMA T, SHIMIZU H, NOJIMA $M$ et al. A novel correlation between LINE-1 hypomethylation and the malignancy of gastrointestinal stromal tumors. Clin Cancer Res 2010; 16: 5114-5123. https://doi. org/10.1158/1078-0432.CCR-10-0581

[15] KPOGHOMOU MA, SOATIANA JE, KALEMBO FW, BISHWAJIT G, SHENG W. UGT2B17 Polymorphism and Risk of Prostate Cancer: A Meta-Analysis. ISRN Oncol 2013; 2013: 465916. https://doi.org/10.1155/2013/465916

[16] KILLIAN JK, MIETTINEN M, WALKER RL, WANG Y, ZHU YJ et al. Recurrent epimutation of SDHC in gastrointestinal stromal tumors. Sci Transl Med 2014; 6: 268 ra177. https://doi.org/10.1126/scitranslmed.3009961

[17] REMACHA L, COMINO-MENDEZ I, RICHTER S, CONTRERAS L, CURRAS-FREIXES $M$ et al. Targeted Exome Sequencing of Krebs Cycle Genes Reveals Candidate Cancer-Predisposing Mutations in Pheochromocytomas and Paragangliomas. Clin Cancer Res 2017; 23: 6315-6324. https://doi.org/10.1158/1078-0432.CCR-16-2250

[18] NANNINIM, ASTOLFI A, URBINIM, INDIO V, SANTINID et al. Integrated genomic study of quadruple-WT GIST (KIT/ PDGFRA/SDH/RAS pathway wild-type GIST). BMC Cancer 2014; 14: 685. https://doi.org/10.1186/1471-2407-14-685

[19] TSANG VH, DWIGHT T, BENN DE, MEYER-ROCHOW GY, GILL AJ et al. Overexpression of miR-210 is associated with SDH-related pheochromocytomas, paragangliomas, and gastrointestinal stromal tumours. Endocr Relat Cancer 2014; 21: 415-426. https://doi.org/10.1530/ERC-13-0519

[20] LANCASTER CR. Succinate:quinone oxidoreductases: an overview. Biochim Biophys Acta 2002; 1553: 1-6.

[21] MAILLOUX RJ, BERIAULT R, LEMIRE J, SINGH R, CHENIER DR et al. The Tricarboxylic Acid Cycle, an Ancient Metabolic Network with a Novel Twist. PLoS One 2007; 2: e690. https://doi.org/10.1371/journal.pone.0000690

[22] PANTALEO MA, ASTOLFI A, INDIO V, MOORE R, THIESSEN $\mathrm{N}$ et al. SDHA loss-of-function mutations in KIT-PDGFRA wild-type gastrointestinal stromal tumors identified by massively parallel sequencing. J Natl Cancer Inst 2011; 12: 983-987. https://doi.org/10.1093/jnci/djr130

[23] BELINSKY MG, CAI KQ, ZHOU Y, LUO B, PEI J et al. Succinate dehydrogenase deficiency in a PDGFRA mutated GIST. BMC Cancer 2017; 17: 512. https://doi.org/10.1186/ s12885-017-3499-7

[24] PANTALEO MA, NANNINI M, CORLESS CL, HEINRICH MC. Quadruple wild-type (WT) GIST: defining the subset of GIST that lacks abnormalities of KIT, PDGFRA, SDH, or RAS signaling pathways. Cancer Med 2015; 4: 101-103. https://doi.org/10.1002/cam4.325

[25] PANTALEO MA, ASTOLFI A, URBINI M, NANNINI M, PATERINI P et al. Analysis of all subunits, SDHA, SDHB, SDHC, SDHD, of the succinate dehydrogenase complex in KIT/PDGFRA wild-type GIST. Eur J Hum Genet 2014; 22 : 32-39. https://doi.org/10.1038/ejhg.2013.80

[26] NISHIDA T, KANDA T, NISHITANI A, TAKAHASHI T, NAKAJIMA $\mathrm{K}$ et al. Secondary mutations in the kinase domain of the KIT gene are predominant in imatinib-resistant gastrointestinal stromal tumor. Cancer Sci 2008; 99: 799804. https://doi.org/10.1111/j.1349-7006.2008.00727.x 
[27] ANTONESCU CR, BESMER P, GUO T, ARKUN K, HOM $\mathrm{G}$ et al. Acquired resistance to imatinib in gastrointestinal stromal tumor occurs through secondary gene mutation. Clin Cancer Res 2005; 11: 4182-4190. https://doi. org/10.1158/1078-0432.CCR-04-2245

[28] GRAMZA AW, CORLESS CL, HEINRICH MC. Resistance to Tyrosine Kinase Inhibitors in Gastrointestinal Stromal Tumors. Clin Cancer Res 2009; 15: 7510-7518. https://doi. org/10.1158/1078-0432.CCR-09-0190

[29] AKCAKAYA P, CARAMUTA S, AHLEN J, GHADERI M, BERGLUND E et al. microRNA expression signatures of gastrointestinal stromal tumours: associations with imatinib resistance and patient outcome. Br J Cancer 2014; 111: 20912102. https://doi.org/10.1038/bjc.2014.548

[30] SIOULAS AD, VASILATOU D, PAPPA V, DIMITRIADIS G, TRIANTAFYLLOU K. Epigenetics in gastrointestinal stromal tumors: clinical implications and potential therapeutic perspectives. Dig Dis Sci 2013; 58: 3094-3102. https://doi. org/10.1007/s10620-013-2785-8

[31] RONNEKLEIV-KELLY SM, SHARMA A, AHUJA N. Epigenetic therapy and chemosensitization in solid malignancy. Cancer Treat Rev 2017; 55: 200-208. https://doi. org/10.1016/j.ctrv.2017.03.008

[32] SHARMA S, KELLY TK, JONES PA. Epigenetics in cancer. Carcinogenesis 2010; 31: 27-36. https://doi.org/10.1093/carcin/bgp220

[33] HALUSKOVA J. Epigenetic studies in human diseases. Folia Biol (Praha) 2010; 56: 83-96.

[34] KOUZARIDES T. Chromatin modifications and their function. Cell 2007; 128: 693-705. https://doi.org/10.1016/j. cell.2007.02.005

[35] BARROW TM, MICHELS KB. Epigenetic epidemiology of cancer. Biochem Biophys Res Commun 2014; 455: 70-83. https://doi.org/10.1016/j.bbrc.2014.08.002

[36] BONETTA L Epigenomics: The new tool in studying complex diseases. Nat Educ 2008; 1: 178.

[37] GREER EL, SHI Y. Histone methylation: a dynamic mark in health, disease and inheritance. Nat Rev Genet 2012; 13: 343-357. https://doi.org/10.1038/nrg3173

[38] HANDY DE, CASTRO R, LOSCALZO J. Epigenetic modifications: basic mechanisms and role in cardiovascular disease. Circulation 2011; 123: 2145-2156. https://doi.org/10.1161/ CIRCULATIONAHA.110.956839

[39] BECKER PB, WORKMAN JL. Nucleosome Remodeling and Epigenetics. Cold Spring Harb Perspect Biol 2013; 5: a017905. https://doi.org/10.1101/cshperspect.a017905

[40] NING B, LI W, ZHAO W, WANG R. Targeting epigenetic regulations in cancer. Acta Biochim Biophys 2016; 48: 97109. https://doi.org/10.1093/abbs/gmv116

[41] COPELAND RA, OLHAVA EJ, SCOTT MP. Targeting epigenetic enzymes for drug discovery. Curr Opin Chem Biol 2010; 14: 505-510. https://doi.org/10.1016/j. cbpa.2010.06.174

[42] YANG Z, JONES A, WIDSCHWENDTER M, TESCHENDORFF AE. An integrative pan-cancer-wide analysis of epigenetic enzymes reveals universal patterns of epigenomic deregulation in cancer. Genome Biology 2015; 16: 140. https:// doi.org/10.1186/s13059-015-0699-9
[43] COPELAND RA, SOLOMON ME, RICHON VM. Protein methyltransferases as a target class for drug discovery. Nat Rev Drug Discov 2009; 8: 724-732. https://doi.org/10.1038/ nrd2974

[44] PLASS C, PFISTER SM, LINDROTH AM, BOGATYROVA $\mathrm{O}$, CLAUS R et al. Mutations in regulators of the epigenome and their connections to global chromatin patterns in cancer. Nat Rev Genet 2013; 14: 765-780. https://doi.org/10.1038/ nrg3554

[45] KIM MS, LEE J, SIDRANSKY D. DNA methylation markers in colorectal cancer. Cancer Metastasis Rev 2010; 29: 181206. https://doi.org/10.1007/s10555-010-9207-6

[46] MERSAKOVA S, NACHAJOVA M, SZEPE P, KASAJOVA PS, HALASOVA E. DNA methylation and detection of cervical cancer and precancerous lesions using molecular methods. Tumour Biol 2016; 37: 23-27. https://doi.org/10.1007/ s13277-015-4197-1

[47] DEATON AM, BIRD A CpG islands and the regulation of transcription. Genes Dev 2011; 25: 1010-1022. doi: 10.1101/ gad.2037511

[48] HE M, FAN J, JIANG R, TANG WX, WANG ZW. Expression of DNMTs and MBD2 in GIST. Biomed Rep 2013; 1: 223-227. https://doi.org/10.3892/br.2012.34

[49] SUZUKI H, TOYOTA M, SATO H, SONODA T, SAKAUCHI $\mathrm{F}$ et al. Roles and causes of abnormal DNA methylation in gastrointestinal cancers. Asian Pac J Cancer Prev 2006;7: 177-185.

[50] KANAI Y, HIROHASHI S Alterations of DNA methylation associated with abnormalities of DNA methyltransferases in human cancers during transition from a precancerous to a malignant state. Carcinogenesis 2007; 28: 2434-2442. doi: 10.1093/carcin/bgm206

[51] POGRIBNY IP, RUSYN I. Role of epigenetic aberrations in the development and progression of human hepatocellular carcinoma. Cancer Lett 2014; 342: 223-230. https://doi. org/10.1016/j.canlet.2012.01.038

[52] AGARWAL A, POLINENI R, HUSSEIN Z, VIGODA I, BHAGAT TD et al. Role of epigenetic alterations in the pathogenesis of Barrett's esophagus and esophageal adenocarcinoma. Int J Clin Exp Pathol 2012; 5: 382-396.

[53] KUBATKA P, URAMOVA S, KELLO M, KAJO K, KRUZLIAK P et al. Antineoplastic effects of clove buds (Syzygium aromaticum L.) in the model of breast carcinoma. J Cell Mol Med 2017; 21: 2837-2851. https://doi.org/10.1111/ jcmm.13197

[54] DAS PM, SINGAL R. DNA methylation and cancer. J Clin Oncol 2004; 22: 4632-4642. https://doi.org/10.1200/ JCO.2004.07.151

[55] EHRLICH M. DNA methylation in cancer: too much, but also too little. Oncogene 2002; 21: 5400-5413. https://doi. org/10.1038/sj.onc.1205651

[56] CHOI SH, WORSWICK S, BYUN HM, SHEAR T, SOUSSA JC et al. Changes in DNA methylation of tandem DNA repeats are different from interspersed repeats in cancer. Int J Cancer 2009; 125: 723-729. https://doi.org/10.1002/ ijc. 24384 
[57] BABA Y, MURATA A, WATANABE M, BABA H. Clinical implications of the LINE-1 methylation levels in patients with gastrointestinal cancer. Surg Today 2014; 44: 18071816. https://doi.org/10.1007/s00595-013-0763-6

[58] GROMOVA P, RUBIN BP, THYS A, CULLUS P, ERNEUX C et al. ENDOGLIN/CD105 is expressed in KIT positive cells in the gut and in gastrointestinal stromal tumours. J Cell Mol Med 2012; 16: 306-317. https://doi.org/10.1111/j.15824934.2011.01315.x

[59] HALLER F, ZHANG JD, MOSKALEV EA, BRAUN A, OTTO $\mathrm{C}$ et al. Combined DNA methylation and gene expression profiling in gastrointestinal stromal tumors reveals hypomethylation of SPP1 as an independent prognostic factor. Int J Cancer 2015;136: 1013-1023. https://doi.org/10.1002/ijc.29088

[60] BAUER S, DUENSING A, DEMETRI GD, FLETCHER JA. KIT oncogenic signaling mechanisms in imatinib-resistant gastrointestinal stromal tumor: PI3-kinase/AKT is a crucial survival pathway. Oncogene 2007; 26: 7560-7568. https:// doi.org/10.1038/sj.onc. 1210558

[61] HALLER F, VON HEYDEBRECK A, ZHANG JD, GUNAWAN B, LANGER C et al. Localization- and mutationdependent microRNA (miRNA) expression signatures in gastrointestinal stromal tumours (GISTs), with a cluster of co-expressed miRNAs located at 14q32.31. J Pathol 2010; 220: 71-86. https://doi.org/10.1002/path.2610

[62] STREUTKER CJ, HUIZINGA JD, DRIMAN DK, RIDDELL RH. Interstitial cells of Cajal in health and disease. Part I: normal ICC structure and function with associated motility disorders. Part II: ICC and gastrointestinal stromal tumours. Histopathology 2007; 50: 176-202. https://doi.org/10.1111/ j.1365-2559.2006.02493.x

[63] SAITO K, SAKURAI S, SANO T, SAKAMOTO K, ASAO $\mathrm{T}$ et al. Aberrant methylation status of known methylationsensitive $\mathrm{CpG}$ islands in gastrointestinal stromal tumors without any correlation to the state of c-kit and PDGFRA gene mutations and their malignancy. Cancer Sci 2008; 99: 253-259. https://doi.org/10.1111/j.1349-7006.2007.00682.x

[64] HOUSE MG, GUO M, EFRON DT, LILLEMOE KD, CAMERON JL et al. Tumor suppressor gene hypermethylation as a predictor of gastric stromal tumor behavior. J Gastrointest Surg 2003; 7: 1004-1014.

[65] WANG Y, SHANG Y. Epigenetic control of epithelial-tomesenchymal transition and cancer metastasis. Exp Cell Res 2013; 319: 160-169. https://doi.org/10.1016/j.yexcr.2012.07.019

[66] JEANES A, GOTTARDI CJ, YAP AS. Cadherins and cancer: how does cadherin dysfunction promote tumor progression? Oncogene 2008; 27: 6920-6929. https://doi.org/10.1038/ onc. 2008.343

[67] HOLUBEKOVA V, MENDELOVA A, GRENDAR M, MERSAKOVA S, KAPUSTOVA I et al. Methylation pattern of $\mathrm{CDH} 1$ promoter and its association with $\mathrm{CDH} 1$ gene expression in cytological cervical specimens. Oncol Lett 2016; 12: 2613-2621. https://doi.org/10.3892/ol.2016.5004

[68] KILLIAN JK, KIM SY, MIETTINEN M, SMITH C, MERINO $\mathrm{M}$ et al. Succinate dehydrogenase mutation underlies global epigenomic divergence in gastrointestinal stromal tumor. Cancer Discov 2013; 3: 648-657. https://doi. org/10.1158/2159-8290.CD-13-0092
[69] URBINI M, ASTOLFI A, INDIO V, HEINRICH MC, CORLESS CL et al. SDHC methylation in gastrointestinal stromal tumors (GIST): a case report. BMC Med Genet 2015; 16: 87. https://doi.org/10.1186/s12881-015-0233-7

[70] YANG J, IKEZOE T, NISHIOKA C, TAKEZAKI Y, HANAZAKI $\mathrm{K}$ et al. Long-term exposure of gastrointestinal stromal tumor cells to sunitinib induces epigenetic silencing of the PTEN gene. Int J Cancer 2012; 130: 959-966. https:// doi.org/10.1002/ijc.26095

[71] LEOTTA M, BIAMONTE L, RAIMONDI L, RONCHETTI D, DI MARTINO MT et al. A p53-dependent tumor suppressor network is induced by selective miR-125a-5p inhibition in multiple myeloma cells. J Cell Physiol 2014; 229: 2106-2116. https://doi.org/10.1002/jcp.24669

[72] ZHUANG HQ, WANG J, YUAN ZY, ZHAO LJ, WANG P et al. The drug-resistance to gefitinib in PTEN low expression cancer cells is reversed by irradiation in vitro. J Exp Clin Cancer Res 2009; 28: 123. https://doi.org/10.1186/17569966-28-123

[73] WU Z, GIOELI D, CONAWAY M, WEBER MJ, THEODORESCU D. Restoration of PTEN Expression Alters the Sensitivity of Prostate Cancer Cells to EGFR Inhibitors. Prostate 2008; 68: 935-944. https://doi.org/10.1002/pros.20745

[74] RICCIR, MAGGIANON, CASTRIF, RINELLI A, MURAZIO $\mathrm{M}$ et al. Role of PTEN in gastrointestinal stromal tumor progression. Arch Pathol Lab Med 2004; 128:421-425. https://doi. org/10.1043/1543-2165(2004)128<421:ROPIGS >2.0.CO;2

[75] SCHNEIDER-STOCK R, BOLTZE C, LASOTA J, MIETTINEN M, PETERS B et al. High Prognostic Value of p16INK4 Alterations in Gastrointestinal Stromal Tumors. J Clin Oncol 2003; 21: 1688-1697. https://doi.org/10.1200/ JCO.2003.08.101

[76] HOUSE MG, GUO M, EFRON DT, LILLEMOE KD, CAMERON JL et al. Tumor suppressor gene hypermethylation as a predictor of gastric stromal tumor behavior. J Gastrointest Surg 2003; 7: 1004-1014

[77] RICCI R, ARENA V, CASTRI F, MARTINI M, MAGGIANO $\mathrm{N}$ et al. Role of p16/INK4a in gastrointestinal stromal tumor progression. Am J Clin Pathol 2004; 122: 35-43. https://doi. org/10.1309/MJ4X-N2M5-7HNC-8X5H

[78] SCHNEIDER-STOCK R, BOLTZE C, LASOTA J, PETERS $B$, CORLESS CL et al. Loss of p16 protein defines high-risk patients with gastrointestinal stromal tumors: a tissue microarray study. Clin Cancer Res 2005;11: 638-645.

[79] PERRONE F, TAMBORINI E, DAGRADA GP, COLOMBO F, BONADIMAN L et al. 9p21 locus analysis in high-risk gastrointestinal stromal tumors characterized for c-kit and platelet-derived growth factor receptor a gene alterations. Cancer 2005; 104: 159-169. https://doi.org/10.1002/cncr.21113

[80] OKAMOTO Y, SAWAKI A, ITO S, NISHIDA T, TAKAHASHI $T$ et al. Aberrant DNA methylation associated with aggressiveness of gastrointestinal stromal tumour. Gut 2012; 61: 392-401. https://doi.org/10.1136/gut.2011.241034

[81] KHAN SA, REDDY D, GUPTA S. Global histone post-translational modifications and cancer: Biomarkers for diagnosis, prognosis and treatment? World J Biol Chem 2015; 6: 333345. https://doi.org/10.4331/wjbc.v6.i4.333 
[82] SWEATT JD, NESTLER EJ, MEANEY MJ, AKBARIAN S An Overview of the Molecular Basis of Epigenetics. pp 3-33. In: JD. Sweatt, EJ. Nestler, MJ Meaney, S. Akbarian (Eds.). Epigenetic Regulation in the Nervous System. Basic Mechanisms and Clinical Impact, 1th Edition. Academic Press 2013, p 374. ISBN 9780123914941.

[83] KANG CH, SONG JJ, LEE J, KIM MY Epigenetics: An emerging player in gastric cancer. World J Gastroenterol 2014; 20 : 6433-6447. https://doi.org/10.3748/wjg.v20.i21.6433

[84] DAWSON MA, KOUZARIDES T. Cancer Epigenetics: From Mechanism to Therapy. Cell 2012; 150: 12-27. https://doi. org/10.1016/j.cell.2012.06.013

[85] QIAO Y, WANG R, YANG X, TANG K, JING N. Dual roles of histone $\mathrm{H} 3$ lysine 9 acetylation in human embryonic stem cell pluripotency and neural differentiation. J Biol Chem 2015; 290: 2508-2520. https://doi.org/10.1074/jbc. M114.603761

[86] KIM SR, KIM KB, CHAE YC, PARK JW, SEO SB. H3S10 phosphorylation-mediated transcriptional regulation by Aurora kinase A. Biochem Biophys Res Commun 2016; 469: 22-28. doi: 10.1016/j.bbrc.2015.11.063

[87] NIINUMA T, SUZUKI H, NOJIMA M, NOSHO K, YAMAMOTO H et al. Upregulation of miR-196a and HOTAIR drive malignant character in gastrointestinal stromal tumors. Cancer Res 2012; 72: 1126-1136. https://doi.org/10.1158/00085472.CAN-11-1803

[88] LIU Y, TSENG M, PERDREAU SA, ROSSI F, ANTONES$\mathrm{CU} \mathrm{C}$ et al. Histone $\mathrm{H} 2 \mathrm{AX}$ is a mediator of gastrointestinal stromal tumor cell apoptosis following treatment with imatinib mesylate. Cancer Res 2007; 67: 2685-2692. https://doi. org/10.1158/0008-5472.CAN-06-3497

[89] RYBAK P, HOANG A, BUJNOWICZ L, BERNAS T, BERNIAK $K$ et al. Low level phosphorylation of histone H2AX on serine $139(\gamma \mathrm{H} 2 \mathrm{AX})$ is not associated with DNA doublestrand breaks. Oncotarget 2016;7: 49574-49587. https://doi. org/10.18632/oncotarget.10411

[90] IHLE MA, TRAUTMANN M, KUENSTLINGER H, HUSS S, HEYDT $C$ et al. miRNA-221 and miRNA-222 induce apoptosis via the KIT/AKT signalling pathway in gastrointestinal stromal tumours. Mol Oncol 2015; 9: 1421-1433. https://doi.org/10.1016/j.molonc.2015.03.013

[91] NANNINI M, RAVEGNINI G, ANGELINI S, ASTOLFI A, BIASCO $\mathrm{G}$ et al. miRNA profiling in gastrointestinal stromal tumors: implication as diagnostic and prognostic markers. Epigenomics 2015; 7: 1033-1049. https://doi.org/10.2217/ epi. 15.52

[92] YU Z, BASERGA R, CHEN L, WANG CH, LISANTI MP et al. microRNA, Cell Cycle, and Human Breast Cancer. Am J Pathol 2010; 176: 1058-1064. https://doi.org/10.2353/ajpath.2010.090664

[93] LEWIS BP, BURGE CB, BARTEL DP. Conserved seed pairing, often flanked by adenosines, indicates that thousands of human genes are microRNA targets. Cell 2005; 120: 15-20. https://doi.org/10.1016/j.cell.2004.12.035

[94] VENKATADRI R, MUNI T, IYER AK, YAKISICH JS, AZAD $\mathrm{N}$. Role of apoptosis-related miRNAs in resveratrol-induced breast cancer cell death. Cell Death Dis 2016; 7: e2104. https://doi.org/10.1038/cddis.2016.6
[95] BUENO MJ, MALUMBRES M. MicroRNAs and the cell cycle. Biochim Biophys Acta 2011; 1812: 592-601. https://doi. org/10.1016/j.bbadis.2011.02.002

[96] VOGLOVA K, BEZAKOVA J, HERICHOVA I. Progress in micro RNA focused research in endocrinology. Endocr Regul 2016; 50: 83-105. https://doi.org/10.1515/enr-2016-0012

[97] KLIMCZAK D, PACZEK L, JAZDZEWSKI K, KUCH M. MicroRNAs: powerful regulators and potential diagnostic tools in cardiovascular disease. Kardiol Pol 2015; 73: 1-6. https://doi.org/10.5603/KP.a2014.0210

[98] KOELZ M, LENSE J, WRBA F, SCHEFFLER M, DIENES $\mathrm{HP}$ et al. Down-regulation of miR-221 and miR-222 correlates with pronounced Kit expression in gastrointestinal stromal tumors. Int J Oncol 2011; 38: 503-511. https://doi. org/10.3892/ijo.2010.857

[99] LIU S, CUI J, LIAO G, ZHANG Y, YE K et al. MiR-137 regulates epithelial-mesenchymal transition in gastrointestinal stromal tumor. Tumour Biol 2014; 35: 9131-9138. https:// doi.org/10.1007/s13277-014-2177-5

[100] FAN R, ZHONG J, ZHENG S, WANG Z, XU Y et al. MicroRNA-218 inhibits gastrointestinal stromal tumor cell and invasion by targeting KIT. Tumour Biol 2014; 35: 4209-4217. https://doi.org/10.1007/s13277-013-1551-z

[101] SUBRAMANIAN S, LUI WO, LEE CH, ESPINOSA I, NIELSEN TO et al. MicroRNA expression signature of human sarcomas. Oncogene 2008; 27: 2015-2026. https://doi. org/10.1038/sj.onc.1210836

[102] FORNARI F, GRAMANTIERI L, FERRACIN M, VERONESE A, SABBIONI S et al. MiR-221 controls CDKN1C/ p57 and CDKN1B/p27 expression in human hepatocellular carcinoma. Oncogene 2008; 27: 5651-5661. https://doi. org/10.1038/onc.2008.178

[103] LEE EJ, GUSEV Y, JIANG J, NUOVO GJ, LERNER MR et al. Expression profiling identifies microRNA signature in pancreatic cancer. Int J Cancer 2007; 120: 1046-1054. https:// doi.org/10.1002/ijc.22394

[104] DUENSING A, MEDEIROS F, MCCONARTY B, JOSEPH NE, PANIGRAHY D et al. Mechanisms of oncogenic KIT signal transduction in primary gastrointestinal stromal tumors (GISTs). Oncogene 2004; 23: 3999-4006. https://doi. org/10.1038/sj.onc. 1207525

[105] TUZLAK S, SCHENK RL, VASANTHAKUMAR A, PRESTON SP, HASCHKA MD et al. The BCL-2 pro-survival protein $\mathrm{A} 1$ is dispensable for $\mathrm{T}$ cell homeostasis on viral infection. Cell Death Differ 2017; 24: 523-533. https://doi. org/10.1038/cdd.2016.155

[106] LI S, WANG C, YU X, WU H, HU J et al. miR-3619-5p inhibits prostate cancer cell growth by activating CDKN1A expression. Oncol Rep 2017; 37: 241-248. https://doi. org/10.3892/or.2016.5250

[107] GUNAWAN B, BERGMANN F, HOER J, LANGER C, SCHUMPELICK et al. Biological and clinical significance of cytogenetic abnormalities in low-risk and high-risk gastrointestinal stromal tumors. Hum Pathol 2002; 33: 316-321.

[108] SEITZ H, ROYO H, BORTOLIN ML, LIN SP, FERGUSONSMITH AC et al. A large imprinted microRNA gene cluster at the mouse Dlk1-Gt12 domain. Genome Res 2004; 14: 1741-1748. https://doi.org/10.1101/gr.2743304 
[109] SCHULTE JH, MARSCHALL T, MARTIN M, ROSENSTIEL $P$, MESTDAGH $P$ et al. Deep sequencing reveals differential expression of microRNAs in favorable versus unfavorable neuroblastoma. Nucleic Acids Res 2010; 38: 5919-5928. https://doi.org/10.1093/nar/gkq342

[110] KIM WK, PARK M, KIM YK, TAE YK, YANG HK et al. MicroRNA-494 downregulates KIT and inhibits gastrointestinal stromal tumor cell proliferation. Clin Cancer Res 2011; 17: 7584-7594. https://doi.org/10.1158/1078-0432.CCR-11-0166

[111] LIU B, TIAN Y, LI F, ZHAO Z, JIANG X et al. Tumor-suppressing roles of miR-214 and miR-218 in breast cancer. Oncol Rep 2016; 35: 3178-3184. https://doi.org/10.3892/ or.2016.4749

[112] LIU Z, XU Y, LONG J, GUO K, GE CH et al. microRNA-218 suppresses the proliferation, invasion and promotes apoptosis of pancreatic cancer cells by targeting HMGB1. Chin J Cancer Res 2015; 27: 247-257. https://doi.org/10.3978/j. issn.1000-9604.2015.04.07

[113] SHI ZM, WANG L, SHEN H, JIANG CF, GE X et al. Downregulation of miR-218 contributes to epithelial-mesenchymal transition and tumor metastasis in lung cancer by targeting Slug/ZEB2 signaling. Oncogene 2017; 36: 2577-2588. https://doi.org/10.1038/onc.2016.414

[114] WANG H, LI M, ZHANG R, WANG Y, ZANG W et al. Effect of miR-335 upregulation on the apoptosis and invasion of lung cancer cell A549 and H1299. Tumour Biol 2013; 34: 3101-3109. https://doi.org/10.1007/s13277-013-0878-9

[115] HERCEG Z, VAISSIERE T. Epigenetic mechanisms and cancer: an interface between the environment and the genome. Epigenetics 2011; 6: 804-819. https://doi.org/10.4161/ epi.6.7.16262

[116] NISHIDA N, MIMORI K, FABBRI M, YOKOBORI T, SUDO T et al. MicroRNA-125a-5p is an independent prognostic factor in gastric cancer and inhibits the proliferation of human gastric cancer cells in combination with trastuzumab. Clin Cancer Res 2011; 17: 2725-2733. https://doi. org/10.1158/1078-0432.CCR-10-2132

[117] KASTL L, BROWN I, SCHOFIELD AC. miRNA-34a is associated with docetaxel resistance in human breast cancer cells. Breast Cancer Res Treat 2012; 131: 445-454. https:// doi.org/10.1007/s10549-011-1424-3

[118] SUN YM, LIN KY, CHEN YQ. Diverse functions of miR-125 family in different cell contexts. J Hematol Oncol 2013; 6: 6. https://doi.org/10.1186/1756-8722-6-6

[119] MAHADEVAN D, COOKE L, RILEY C, SWART R, SIMONS B et al. A novel tyrosine kinase switch is a mechanism of imatinib resistance in gastrointestinal stromal tumors. Oncogene 2007; 26: 3909-3919. https://doi.org/10.1038/ sj.onc. 1210173

[120] WANG HM, XU YF, NING SL, YANG DX, LI Y et al. The catalytic region and PEST domain of PTPN18 distinctly regulate the HER2 phosphorylation and ubiquitination barcodes. Cell Res 2014; 24: 1067-1090. https://doi.org/10.1038/ cr.2014.99

[121] HENDRIKS WJ, BOHMER FD. Non-transmembrane PTPs in Cancer, pp 47-113. In: BG. Neel, NK. Tonks (Eds.). Protein Tyrosine Phosphatases in Cancer. Springer-Verlag, New York 2016, p. 360. ISBN 978-1-4939-3647-2
[122] TAKAHASHI T, SERADA S, AKO M, FUJIMOTO M, MIYAZAKI Y et al. New findings of kinase switching in gastrointestinal stromal tumor under imatinib using phosphoproteomic analysis. Int J Cancer 2013; 133: 2737-2743. https:// doi.org/10.1002/ijc.28282

[123] ZHOU P, JIANG W, WU L, CHANG R, WU K et al. miR$301 \mathrm{a}$ is a candidate oncogene that targets the homeobox gene Gax in human hepatocellular carcinoma. Dig Dis Sci 2012; 57: 1171-1180. https://doi.org/10.1007/s10620-012-2099-2

[124] CAO CL, NIU HJ, KANG SP, CONG CL, KANG SR. miRNA-21 sensitizes gastrointestinal stromal tumors (GISTs) cells to Imatinib via targeting B-cell lymphoma 2 (Bcl-2). Eur Rev Med Pharmacol Sci 2016; 20: 3574-3581.

[125] WANG Q, LIU S, TANG Y, LIU Q, YAO Y. MPT64 protein from Mycobacterium tuberculosis inhibits apoptosis of macrophages through NF-kB-miRNA21-Bcl-2 pathway. PLoS One 2014; 9: e100949. https://doi.org/10.1371/journal. pone.0100949

[126] GAO X, SHEN K, WANG C, LING J, WANG H et al. MiR320 a downregulation is associated with imatinib resistance in gastrointestinal stromal tumors. Acta Biochim Biophys Sin (Shanghai) 2014; 46: 72-75. https://doi.org/10.1093/ abbs/gmt118

[127] ZHANG T, ZOU P, WANG T, XIANG J, CHENG J et al. Down-regulation of miR-320 associated with cancer progression and cell apoptosis via targeting Mcl-1 in cervical cancer. Tumour Biol 2016; 37: 8931-8940. https://doi.org/10.1007/ s13277-015-4771-6

[128] VESUNA F, VAN DIEST P, CHEN JH, RAMAN V. Twist is a transcriptional repressor of E-cadherin gene expression in breast cancer. Biochem Biophys Res Commun 2008; 367: 235-241. https://doi.org/10.1016/j.bbrc.2007.11.151

[129] QIN Q, XU Y, HE T, QIN C, XU J. Normal and diseaserelated biological functions of Twist1 and underlying molecular mechanisms. Cell Res 2012; 22: 90-106. https://doi. org/10.1038/cr.2011.144

[130] YANG Y, WANG G, ZHU D, HUANG Y, LUO Y et al. Epithelial-mesenchymal transition and cancer stem cell-like phenotype induced by Twist 1 contribute to acquired resistance to irinotecan in colon cancer. Int J Oncol 2017; 51: 515-524. https://doi.org/10.3892/ijo.2017.4044

[131] DONG S, JIN M, LI Y, REN P, LIU J. MiR-137 acts as a tumor suppressor in papillary thyroid carcinoma by targeting CXCL12. Oncol Rep 2016; 35: 2151-2158. https://doi. org/10.3892/or.2016.4604

[132] GUO J, XIA B, MENG F, LOU G. miR-137 suppresses cell growth in ovarian cancer by targeting AEG-1. Biochem Biophys Res Commun 2013; 441: 357-363. https://doi. org/10.1016/j.bbrc.2013.10.05

[133] LIU S, LIAO G, DING J, YE K, ZHANG Y et al. Dysregulated expression of Snail and E-cadherin correlates with gastrointestinal stromal tumor metastasis. Eur J Cancer Prev 2014; 23: 329-335. https://doi.org/10.1097/CEJ.0000000000000072

[134] TSANG VH, DWIGHT T, BENN DE, MEYER-ROCHOW GY, GILL AJ et al. Overexpression of miR-210 is associated with SDH-related pheochromocytomas, paragangliomas, and gastrointestinal stromal tumours. Endocr Relat Cancer 2014; 21: 415-426. https://doi.org/10.1530/ERC-13-0519 
[135] FASANARO P, GRECO S, LORENZI M, PESCATORI M, BRIOSCHI $\mathrm{M}$ et al. An integrated approach for experimental target identification of hypoxia-induced miR-210. J Biol Chem 2009; 284: 35134-35143. https://doi.org/10.1074/jbc. M109.052779

[136] IYER NV, KOTCH LE, AGANI F, LEUNG SW, LAUGHNER E et al. Cellular and developmental control of $\mathrm{O} 2$ homeostasis by hypoxia-inducible factor 1 alpha. Genes Dev 1998; 12: 149-162.

[137] WISE DR, WARD PS, SHAY JE, CROSS JR, GRUBER JJ Hypoxia promotes isocitrate dehydrogenasedependent carboxylation of $\alpha$-ketoglutarate to citrate to support cell growth and viability. Proc Natl Acad Sci U S A 2011; 108: 1961119616. https://doi.org/10.1073/pnas.1117773108

[138] CHEN WT, HUANG CJ, WU MT, YANG SF, SU YC et al. Hypoxia-inducible Factor-1a is Associated with Risk of Aggressive Behavior and Tumor Angiogenesis in Gastrointestinal Stromal Tumor. Jpn J Clin Oncol 2005; 35: 207-213. https://doi.org/10.1093/jjco/hyi067

[139] TAKAHASHI R, TANAKA S, HIYAMA T, ITO M, KITADAI $Y$ et al. Hypoxia-inducible factor-1alpha expression and angiogenesis in gastrointestinal stromal tumor of the stomach. Oncol Rep 2003; 10: 797-802.

[140] LU YC, CHANG JT, CHAN EC, CHAO YK, YEH TS et al. miR-196, an Emerging Cancer Biomarker for Digestive Tract Cancers. J Cancer 2016; 7: 650-655. https://doi.org/10.7150/ jca.1346

[141] WANG J, CHEN J, CHANG P, LEBLANC A, LI D et al. MicroRNAs in plasma of pancreatic ductal adenocarcinoma patients as novel blood-based biomarkers of disease. Cancer Prev Res (Phila) 2009; 2: 807-813. https://doi. org/10.1158/1940-6207.CAPR-09-0094

[142] LI Y, ZHANG M, CHEN H, DONG Z, GANAPATHY V et al. Ratio of miR-196s to HOXC8 messenger RNA correlates with breast cancer cell migration and metastasis. Cancer Res 2010; 70: 7894-7904. https://doi.org/10.1158/0008-5472. CAN-10-1675

[143] KHALIL AM, GUTTMAN M, HUARTE M, GARBER M, RAJ A et al. Many human large intergenic noncoding RNAs associate with chromatin-modifying complexes and affect gene expression. Proc Natl Acad Sci U S A 2009; 106: 1166711672. https://doi.org/10.1073/pnas.0904715106

[144] HAJJARI M, SALAVATY A. HOTAIR: an oncogenic long non-coding RNA in different cancers. Cancer Biol Med 2015; 12: 1-9. https://doi.org/10.7497/j.issn.2095-3941.2015.0006

[145] GUPTA RA, SHAH N, WANG KC, KIM J, HORLINGS HM et al. Long non-coding RNA HOTAIR reprograms chromatin state to promote cancer metastasis. Nature 2010; 464: 1071-1076. https://doi.org/10.1038/nature08975

[146] YAMAMOTO H, KOHASHI K, FUJITA A, ODA Y. Fascin-1 overexpression and miR-133b downregulation in the progression of gastrointestinal stromal tumor. Mod Pathol 2013; 26: 563-571. https://doi.org/10.1038/modpathol.2012.198

[147] PANTALEO MA, RAVEGNINI G, ASTOLFI A, SIMEON V, NANNINI $M$ et al. Integrating miRNA and gene expression profiling analysis revealed regulatory networks in gastrointestinal stromal tumors. Epigenomics 2016; 8: 1347-1366. https://doi.org/10.2217/epi-2016-0030
[148] BADER AG, BROWN D, STOUDEMIRE J, LAMMERS P. Developing therapeutic microRNAs for cancer. Gene Ther 2011; 18: 1121-1126. https://doi.org/10.1038/gt.2011.79

[149] HOSSEINAHLI N, AGHAPOUR M, DUIJF PHG, BARADARAN B. Treating cancer with microRNA replacement therapy: A literature review. J Cell Physiol. 2018, 233: 5574-5588. doi: $10.1002 /$ jcp. 26514

[150] BADER AG, BROWN D, WINKLER M. The promise of microRNA replacement therapy. Cancer Res 2010; 70: 70277030. https://doi.org/10.1158/0008-5472.CAN-10-2010

[151] WIGGINS JF, RUFFINO L, KELNAR K, OMOTOLA M, PATRAWALA L et al. Development of a lung cancer therapeutic based on the tumor suppressor microRNA-34. Cancer Res 2010; 70: 5923-5930. https://doi.org/10.1158/0008-5472. CAN-10-0655

[152] LIU C, KELNAR K, LIU B, CHEN X, CALHOUN-DAVIS T et al. The microRNA miR-34a inhibits prostate cancer stem cells and metastasis by directly repressing CD44. Nat Med 2011; 17: 211-215. https://doi.org/10.1038/nm.2284

[153] DAVIS ME, CHEN ZG, SHIN DM. Nanoparticle therapeutics: an emerging treatment modality for cancer. Nat Rev Drug Discov 2008; 7: 771-782. https://doi.org/10.1038/ $\operatorname{nrd} 2614$

[154] WIGGINS JF, RUFFINO L, KELNAR K, OMOTOLA M, PATRAWALA L et al. Development of a lung cancer therapeutic based on the tumor suppressor microRNA-34. Cancer Res 2010; 70: 5923-5930. https://doi.org/10.1158/0008-5472. CAN-10-0655

[155] ROTH JA. Adenovirus p53 gene therapy. Expert Opin Biol Ther 2006; 6: 55-61. https://doi.org/10.1517/14712598.6.1.55

[156] THORSEN SB, OBAD S, JENSEN NF, STENVANG J, KAUPPINEN S. The therapeutic potential of microRNAs in cancer. Cancer J 2012; 18: 275-284. https://doi.org/10.1097/ PPO.0b013e318258b5d6

[157] LI H, CHIAPPINELLI KB, GUZZETTA AA, EASWARAN $\mathrm{H}$, YEN RW et al. Immune regulation by low doses of the DNA methyltransferase inhibitor 5-azacitidine in common human epithelial cancers. Oncotarget 2014; 5: 587-598. https://doi.org/10.18632/oncotarget.1782

[158] WELLS RA, LEBER B, ZHU NY, STORRING JM. Optimizing outcomes with azacitidine: recommendations from $\mathrm{Ca}$ nadian centres of excellence. Curr Oncol 2014; 21: 44-50. https://doi.org/10.3747/co.21.1871

[159] ZAGNI C, CHIACCHIO U, RESCIFINA A. Histone Methyltransferase Inhibitors: Novel Epigenetic Agents for Cancer Treatment. Curr Med Chem 2013; 20: 167-185.

[160] CHRISTMAN JK, SCHNEIDERMAN N, ACS G. Formation of highly stable complexes between 5-azacytosine-substituted DNA and specific non-histone nuclear proteins. Implications for 5-azacytidine-mediated effects on DNA methylation and gene expression. J Biol Chem 1985; 260: 4059-4068.

[161] YANG X, LAY F, HAN H, JONES PA. Targeting DNA Methylation for Epigenetic Therapy. Trends Pharmacol Sci 2010; 31: 536-546. https://doi.org/10.1016/j.tips.2010.08.001

[162] QIN T, JELINEK J, SI J, SHU J, ISSA JP. Mechanisms of resistance to 5-aza-2'-deoxycytidine in human cancer cell lines. Blood 2009; 113: 659-667. https://doi.org/10.1182/ blood-2008-02-140038 
[163] LU D. Epigenetic modification enzymes: catalytic mechanisms and inhibitors. Acta Pharm Sinica B 2013; 3: 141-149. http://dx.doi.org/10.1016/j.apsb.2013.04.007

[164] CHUANG JC, YOO CB, KWAN JM, LI TW, LIANG G et al. Comparison of biological effects of non-nucleoside DNA methylation inhibitors versus 5-aza-2V-deoxycytidine. Mol Cancer Ther 2005; 4: 1515-1520. https://doi. org/10.1158/1535-7163.MCT-05-0172

[165] SLINGERLAND M, GUCHELAAR HJ, GELDERBLOM H. Histone deacetylase inhibitors: an overview of the clinical studies in solid tumors. Anticancer Drugs 2014; 25: 140-149. https://doi.org/10.1097/CAD.0000000000000040

[166] RAMACHANDRAN S, IENT J, GÖTTGENS EL, KRIEG AJ, HAMMOND EM. Epigenetic Therapy for Solid Tumors: Highlighting the Impact of Tumor Hypoxia. Genes (Basel) 2015; 6: 935-956. https://doi.org/10.3390/genes6040935

[167] MUHLENBERG T, ZHANG Y, WAGNER AJ, GRABELLUS F, BRADNER J et al. Inhibitors of deacetylases suppress oncogenic KIT signaling, acetylate HSP90, and induce apoptosis in gastrointestinal stromal tumors. Cancer Res 2009; 69: 6941-6950. https://doi.org/10.1158/0008-5472.CAN-084004

[168] GOŁĄBEK K, STRZELCZYK JK, WICZKOWSKI A, MICHALSKI M. Potential use of histone deacetylase inhibitors in cancer therapy. Contemp Oncol (Pozn) 2015; 19: 436-440. https://doi.org/10.5114/wo.2015.51824

[169] SPANNHOFF A, SIPPL W, JUNG M. Cancer treatment of the future: inhibitors of histone methyltransferases. Int $\mathrm{J}$ Biochem Cell Biol 2009; 41: 4-11. https://doi.org/10.1016/j. biocel.2008.07.024

[170] JACKSON SE. Hsp90: structure and function. Top Curr Chem 2013; 328: 155-240. https://doi.org/10.1007/128_2012_356

[171] DUMONT AG, YANG Y, REYNOSO D, KATZ D, TRENT JC et al. Anti-tumor effects of the Notch pathway in gastrointestinal stromal tumors. Carcinogenesis 2012; 33: 16741683. https://doi.org/10.1093/carcin/bgs221

[172] ALTURKMANI HJ, PESSETTO ZY, GODWIN AK. Beyond standard therapy: drugs under investigation for the treatment of gastrointestinal stromal tumor. Expert Opin Investig Drugs 2015; 24: 1045-1058. https://doi.org/10.1517/1354378 4.2015 .1046594
[173] GU ML, WANG YM, ZHOU XX, YAO HP, ZHENG S et al. An inhibitor of the acetyltransferases CBP/p300 exerts antineoplastic effects on gastrointestinal stromal tumor cells. Oncol Rep 2016; 36: 2763-2770. https://doi.org/10.3892/ or.2016.5080

[174] BAYLIN SB. DNA methylation and gene silencing in cancer. Nat Clin Pract Oncol 2005; 2: S4-S11. https://doi. org/10.1038/ncponc0354

[175] FINNIN MS, DONIGIAN JR, COHEN A, RICHON VM, RIFKIND RA et al. Structures of a histone deacetylase homologue bound to the TSA and SAHA inhibitors. Nature 1999; 401: 188-193. https://doi.org/10.1038/43710

[176] FURUMAI R, MATSUYAMA A, KOBASHI N, LEE KH, NISHIYAMA $M$ et al. FK228 (depsipeptide) as a natural prodrug that inhibits class I histone deacetylases. Cancer Res 2002; 62: 4916-4921.

[177] ACCARI SL, FISHER PR. Emerging Roles of JmjC DomainContaining Proteins. Int Rev Cell Mol Biol 2015; 319: 165220. https://doi.org/10.1016/bs.ircmb.2015.07.003

[178] GAUTSCHI O, HEIGHWAY J, MACK PC, PURNELL PR, LARA PN JR et al. Aurora kinases as anticancer drug targets. Clin Cancer Res 2008; 14: 1639-1648. https://doi. org/10.1158/1078-0432.CCR-07-2179

[179] EMANUELE MJ, LAN W, JWA M, MILLER SA, CHAN CS et al. Aurora B kinase and protein phosphatase 1 have opposing roles in modulating kinetochore assembly. J Cell Biol 2008; 181: 241-254. https://doi.org/10.1083/jcb.200710019

[180] SHI D, GU W. Dual roles of MDM2 in the regulation of p53. Ubiquitination dependent and ubiquitination independent mechanisms of MDM2 repression of p53 activity. Genes Cancer 2012; 3: 240-248. https://doi. org/10.1177/1947601912455199

[181] DARNET S, MOREIRA FC, HAMOY IG, BURBANO R, KHAYAT A et al. High-Throughput Sequencing of miRNAs Reveals a Tissue Signature in Gastric Cancer and Suggests Novel Potential Biomarkers. Bioinform Biol Insights 2015; 9: 1-8. https://doi.org/10.4137/BBI.S23773

[182] CHOI HJ, LEE H, KIM H, KWON JE, KANG HJ et al. MicroRNA expression profile of gastrointestinal stromal tumors is distinguished by $14 \mathrm{q}$ loss and anatomic site. Int J Cancer 2010; 126: 1640-1650. https://doi.org/10.1002/ijc.24897 